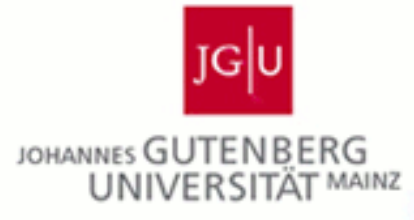

Interdisciplinary Public

Policy Mainz

Gutenberg School of Management and Economics

\& Research Unit "Interdisciplinary Public Policy"

Discussion Paper Series

\title{
Like it or not? How the Economic and Institutional Environment Shapes Individual Attitudes towards Multinational Enterprises
}

Philipp Harms and Jakob Schwab

October 2015

Discussion paper number 1515

Johannes Gutenberg University Mainz

Gutenberg School of Management and Economics

Jakob-Welder-Weg 9

55128 Mainz

Germany

wiwi.uni-mainz.de 
Contact details

Philipp Harms

Johannes Gutenberg University Mainz

Department Law and Economics

Chair of International Economics

Jakob-Welder-Weg 4

55128 Mainz

Email: philipp.harms@uni-mainz.de

Jakob Schwab

Johannes Gutenberg-University Mainz

Department Law and Economics

Chair of International Economics

Jakob-Welder-Weg 4

55128 Mainz

Email: jakob.schwab@uni-mainz.de 


\title{
Like it or not? How the Economic and Institutional Environment Shapes Individual Attitudes towards Multinational Enterprises
}

\author{
Philipp Harms* Jakob Schwab
}

October 2015

\begin{abstract}
This paper analyzes the determinants of people's attitudes towards FDI using a survey-based data set that covers a wide range of rich and poor countries. We find that both individual socioeconomic characteristics and macroeconomic and institutional factors shape agents' attitudes towards multinational firms. Moreover, we find that the influence of an individual's characteristics - such as education and the status as an entrepreneur - depends on the respective country's per-capita income.
\end{abstract}

Keywords: Multinational Firms; FDI; Globalization; Political Economy JEL: F21, F23, F61

*Johannes Gutenberg University Mainz and Study Center Gerzensee, Email: philipp.harms@uni-mainz.de

${ }^{\dagger}$ GSEFM and Johannes Gutenberg University Mainz, E-Mail: jakob.schwab@uni-mainz.de. We are indebted to participants of the 2014 Silvaplana workshop, the 2015 Meeting of the European Public Choice Society, and the 2015 ETSG Conference for valuable comments and to Franziska Collingro for excellent research assistance. 


\section{Introduction}

Over the past 30 years, the integration of goods and factor markets has affected the lives of individuals all over the world. While some agents have reaped enormous benefits from this process, others have lost in terms of income and welfare.1 It is usually argued that individuals are aware of the distributional effects of globalization, and that this knowledge shapes their preferences over various policy issues such as protection, financial market regulation etc. In this paper, we use a large survey-based data set to explore whether this conjecture is correct when it comes to individuals' attitudes towards multinational enterprises (MNEs). We test whether socio-economic characteristics influence these attitudes in the way suggested by economic theory: do those individuals whom theory predicts to gain from the presence of multinational firms - e.g. because they have the opportunity of earning a higher wage actually express a more favorable perception of foreign direct investment (FDI)?

We find that, indeed, younger persons and persons who rank higher in firm hierarchies welcome multinational enterprises. Moreover, a higher income relative to the country-specific average results in a more positive attitude. However, cross-country differences in the average assessment of FDI are substantial, with, e.g., the likelihood of a French person approving the presence of MNE's being almost 30 percent lower than that of an (otherwise identical) Irish person.

In a second step, we attempt to explain these international differences in attitudes by replacing country-specific fixed effects with variables that capture countries' level of development, industrial structure and institutional environment. Interestingly, while per-capita GDP does not seem to affect country-specific averages, the extent of inequality and corruption, the status as a raw materials exporter, financial development, and the degree of "social globalization" have a significant influence.

Finally, we test whether the marginal effect of individual characteristics depends on the country-specific environment. The neoclassical model suggests that the rate of return in capital-scarce countries decreases as a result of financial globalization, while it increases in capital-rich countries. This leads us to the hypothesis that the presence of MNEs is perceived as being more harmful by capital owners in poor countries. Our results confirm this conjecture: we find that, ceteris paribus, firm owners are more critical about FDI in economies with a lower per-capita income. Moreover, we show that the marginal effect of a person's educational attainment on her attitude towards MNEs crucially depends on a country's percapita income, with well-educated people in rich countries adopting a more positive view, and their counterparts in poor economies being rather skeptical towards FDI. This find-

\footnotetext{
1 The distributional effects of globalization have been the subject of numerous theoretical and empirical analyses: see Krugman (2008) and Goldberg and Pavcnik (2007) for respective overviews.
} 
ing is in line with an understanding of multinational enterprises as institutions that engage in horizontal FDI or vertical FDI, and the observation that horizontal FDI, which favors high-skilled workers, prevails in rich countries, while poor countries attract a larger share of vertical FDI (Carr et al., 2001, Davies, 2008). Moreover, our empirical finding supports a view of multinational enterprises as facilitating trade and thus reinforcing specialization patterns along skill endowments (Ortseifer and Schwab, 2015). Following the logic of the Stolper-Samuelson theorem, this should benefit the abundant factor - skilled labor in rich countries, and low-skilled workers in poor countries.

The two papers most closely related to ours are Kaya and Walker (2012) and Mayda and Rodrik (2005). Kaya and Walker (2012) also analyze the opinions about FDI, using the same data set as we do. However, they restrict their analysis to individual determinants of agents' attitudes towards MNEs without considering macroeconomic variables. Mayda and Rodrik (2005) analyze an older vintage of the survey data set we use and focus on the respondents' view on trade liberalization. Moreover, they put a much smaller emphasis on the analysis of macroconomic determinants or the interaction of macroeconomic variables with individual characteristics. Contributions on the effects of popular attitudes towards globalization are provided by Cadot et al. (2006) and Noland (2005): While Cadot et al. (2006) focus on France and show that these attitudes actually affect trade policy, Noland (2005) demonstrates that they have an impact on FDI inflows and country ratings.

The remainder of the paper is organized as follows: The next section 2 presents the primary data used throughout the analysis, while section 3 presents first estimation results on individual determinants of agents' views on FDI. Section 4 analyzes the economic and institutional factors that determine the remaining cross-country differences in average attitudes. In section 5, we then explore how a country's macroeconomic environment influences the marginal effect of indvividual characteristics on the perception of MNEs. A number of robustness tests are pursued in section 6. Section 7 summarizes and concludes.

\section{Primary data}

The International Social Survey Programme (ISSP) organizes national surveys in a broad cross-section of countries, eliciting information on a large set of socially relevant topics. The data we use is from the ISSP 2003 National Identity II module. Across countries, the dataset covers 45,993 individual observations. The respondents are from 35 countries, including developed, emerging and developing countries. The number of individual observations per country ranges from 837 (Great Britain) to 2383 (Russia).

The respondents answer a broad set of questions regarding their feelings towards their na- 
tional identity, including their attitude towards foreign investment, free trade, and international political cooperation. Furthermore, they provide detailed information on their socioeconomic background. This allows us to relate individuals' attitudes towards MNEs to their personal characteristics.

The indicator that we use in order to measure individuals' views on multinational enterprises is the answer to the following question: "How much do you agree or disagree with the following statement? : 'Large international companies are doing more and more damage to local businesses in [your country]'". The respondents are asked to answer on a scale from "Agree strongly" (=1) to "Disagree strongly" $(=5) \mathrm{U}^{2}$ As framed, the statement refers to inward investment only. Although we will cautiously interpret it as a general stand on financial globalization and direct investment, this restriction should be kept in mind ${ }^{3}$.

As our main dependent variable, we use a binary indicator, MNE-PHIL, which takes the value 1 if a respondent does not agree with the statement (i.e. if he or she instead gives the answer 3,4, or 5). Note that we interpret the intermediate answer 3, "Neither agree nor disagree", as being in favor of FDI since the respondent does not explicitly express resentment towards MNEs. Over the entire sample, this applies for roughly $40 \%$ of the population. To check the robustness of our findings with respect to this choice, we will later adopt the alternative view and interpret only explicit disagreement with the statement above (i.e. giving the answer 4 or 5) as being in favor of multinational enterprises. The resulting binary depen-

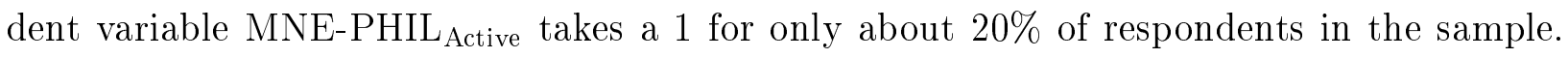
Finally, as an alternative to these binary variables, we create a categorical variable MNEATT along a 3-class-scale. MNE-ATT takes the value 1 if respondents (strongly) agree, 2 if they neither agree nor disagree, and 3 if they (strongly) disagree with the statement. As with MNE-PHIL, a higher value of the dependent variable can thus be interpreted as a more favorable attitude towards MNEs. ${ }^{4}$

Across countries, there is a high variation in the average national response. France shows the lowest average value of MNE-PHIL (0.21) whereas people in Sweden reveal, on average, the most positive opinion on FDI (average MNE- PHIL of 0.58). The average values of MNEPHIL for the countries in our sample are presented in Figure 1 .

In addition to the information about attitudes towards multinational enterprises, the

\footnotetext{
${ }^{2}$ We capture this answer in the variable $M N E_{\text {Damage }}$

${ }^{3}$ It has been shown in other contexts that respondents tend to answer this type of questions similarly whether for their own country only or in general terms (see e.g. Scheve and Slaughter, 2001).

${ }^{4}$ The overall rather negative view on FDI that is revealed by the widespread agreement with the statement may raise the question whether the framing might bias the average answer. However, since we are interested in the determinants of relative individual attitudes, the variation across respondents should provide us with good information on what makes it more likely that a person has a more positive or more negative view on multinationals.
} 


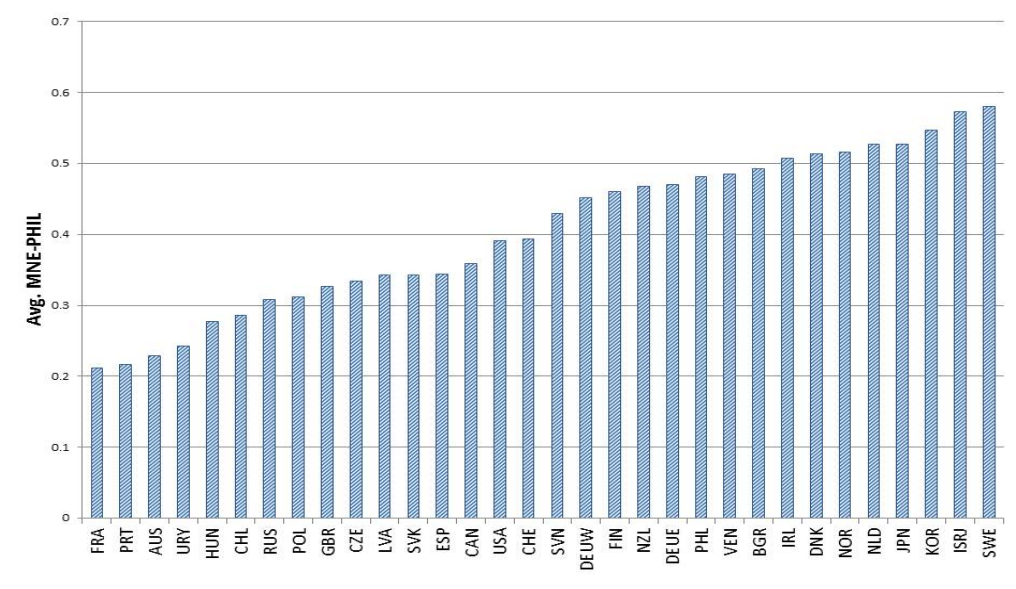

Figure 1: Average value of MNE-PHIL, i.e. share of persons who do not (strongly) agree with the statement that "large international companies are doing more and more damage to local businesses in [our country]".

ISSP survey also elicits a wide range of information on respondents' socioeconomic background. In our baseline estimations, we include information on gender, age, education, income, and employment status as our main explanatory variables on the individual level. Male is a gender dummy. For education, we take the highest Degree of a person, ranging from $1=$ "no formal education" to $5=$ "university degree completed". We proxy for the position in firm hierarchies by creating a dummy that reflects whether a respondent supervises others at work (WrkSup), which could also possibly represent informal qualification. Moreover, the relative income position of the person in her society is included (RelIncome), computed as the respondent's annual income relative to the sample average in his or her respective country.

The data does not provide information on capital ownership, but it gives information on whether a respondent is self-employed, and if so, how many people he or she employs. From this information, we will define as a firm owner anyone who is self-employed and employs more than 10 people (dummy FirmOwn). In our sample, 5,135 out of 45,993 responents $(\approx 11 \%)$ declare to be self-employed. Of these, about $7.2 \%$ report to employ more than 10 employees ( 374 respondents, $\approx 0.88 \%$ of 42,504 respondents who gave information on their self-employment status and the respective number of employees)..$^{5}$ Finally, to account for the possibility that the attitude towards MNEs is predominantly driven by individuals' attitudes towards everything that is foreign, we use the response to the following statement: "Gen-

\footnotetext{
${ }^{5}$ Our results are robust to any other reasonable employment cutoff for the definition of firm ownership. We use the cutoff of 10 employees because, for Germany, any number of employees between 2 and 9 is reported as 9 .
} 
erally speaking, [your country] is a better country than most other countries", as a control variable. Again, responses vary on a scale from 1, "agree strongly", to 5, "disagree strongly". This is our variable Cosmopol. A higher value should hence proxy for a less nationalist, more cosmopolitan attitude.

The survey was conducted in 2003. A list of the ISSP variables we use and their interpretation (table 9), as well as summary statistics of these respondent-specific variables (table 10) are given in appendix A. Typically, not all questions were asked in all countries, so that we exclude these countries (South Africa and Austria) from the analysis. Taiwan and the Arab part of Israel are excluded, too, because, for lack of macroeconomic variables, we will have to drop them from the analysis later, and we want to keep the sample comparable. This leaves us with observations from 32 countries. Among these, we delete all observations where respondents picked "Can't choose", "NA, refused" as answers in variables of interest, and remain with roughly 25,000 observations in most specifications.

\section{Socioeconomic Determinants}

We start by analyzing how personal characteristics determine individuals' attitude towards MNEs. There are good reasons to believe that they do. We conjecture that persons who are more likely to profit from the presence of multinational enterprises are also more prone to be in favor of these enterprises, and look for whether this can indeed be seen in the data. We therefore test whether individual characteristics that should enable someone to benefit from FDI also positively influence attitudes towards FDI. Work in multinational enterprises is likely to be particularly skill demanding - e.g. because of required language skills or a more elaborate use of technology. We therefore expect workers with higher educational attainments - as reflected by the variable Degree - to have an especially positive attitude towards MNEs. The skills that allow a person to benefit from FDI need not necessarily stem from acquiring a formal degree. We proxy for this by the level of the work position which is obtained, e.g. because a person had vocational training or acquired skills through learning-

by-doing. This is captured by whether someone supervises others at work or not, indicated by the dummy variable WrkSup. Age might play a role since human capital depreciates over time such that younger people are in a better position to meet the skill requirements of multinational enterprises. We also test for a gender effect in order to account for the possibility that e.g. women may generally be discriminated against on the labor market, such that Males would be more positive towards FDI.

A more favorable economic position, as measured by the variable RelIncome, should - for both economic and social reasons - bring about a more positive attitude towards multina- 
tionals: first, the generally higher life-satisfaction that is associated with a higher relative income is likely to result in a rather optimistic view on the functioning of the economy, including the presence of MNEs. Moreover, a higher relative income is also likely to reflect other factors that enable a person to benefit from FDI, be it as an employee or as a customer. Owning a firm, as defined above (FirmOwn), is (beyond its indirect impact via a higher income) likely to influence the perspective on the presence of MNEs, although we do not have a clear hypothesis on the direction of this effect: due to increased competition it could be negative, or it could be positive due to spillover effects.

We test the influence of these individual characteristics on the attitude towards MNEs by running the following regression:

$$
M N E-P H I L_{i c}=\boldsymbol{\beta}^{\prime} \boldsymbol{X}_{i c}+\alpha_{c}+\epsilon_{i c}
$$

MNE - PHIL $L_{i c}$ represents the realization of MNE-PHIL or MNE-ATT for individual $i$ living in country $c, \boldsymbol{X}_{\boldsymbol{i c}}$ is the set of individual characteristics, $\alpha_{c}$ is a country dummy and $\epsilon_{i c}$ is an error term. The use of country fixed effects ensures that our results capture the pure individual effects, while eliminating all country-specific differences in answers.

We run equation (1) as an OLS linear probability model (LPM) and as a logit model on the binary dependent variable MNE-PHIL. When using the 3-scale categorical dependent variable MNE-ATT as regressand, we apply an ordered logit model. For all three specifications, standard errors are clustered at the country level to control for the possibility that disturbances are correlated between respondents in the same country. For OLS and ordered logit, we report the estimated coefficients. For logit, marginal effects are displayed. The results can then be interpreted as the increase in the probability to have a more positive view on MNEs.

Table 1 reports the results. We find that, indeed, better educated and younger persons are more likely to adopt a favorable attitude towards FDI, as are those in a higher work hierarchy position, in line with our expectations. Note that since we are controling for Cosmopol - whose coefficient is significantly positive, as expected - the effect of Degree is not driven by the effect of education on the general xenophobia of a person. Nevertheless, the positive coefficent of Degree could still reflect the fact that education changes the understanding of the role of MNEs, independent of the underlying peronal affectedness. For the positive effect of WrkSup, this is less probable, and it is likely that it represents a direct economic effect. Firm ownership itself has no significant effect, although the sign of the coefficient is positive. The relative income position within a country, by contrast, does have a significantly positive effect on perceptions of FDI. Overall, we can conclude that people in a better economic position are more likely to take a positive stand on FDI. This confirms results by Kaya and 


\begin{tabular}{|c|c|c|c|}
\hline & (1) & (2) & (3) \\
\hline VARIABLES & $\begin{array}{c}\text { OLS } \\
\text { MNE-PHIL }\end{array}$ & $\begin{array}{c}\text { Logit } \\
\text { MNE-PHIL }\end{array}$ & $\begin{array}{l}\text { OLogit } \\
\text { MNE-ATT }\end{array}$ \\
\hline Male & $\begin{array}{c}0.0096 \\
(0.0076)\end{array}$ & $\begin{array}{c}0.0093 \\
(0.0073)\end{array}$ & $\begin{array}{c}0.099^{* * *} \\
(0.034)\end{array}$ \\
\hline Age & $\begin{array}{c}-0.0017^{* * *} \\
(0.00033)\end{array}$ & $\begin{array}{c}-0.0017^{* * *} \\
(0.00032)\end{array}$ & $\begin{array}{c}-0.0074^{* * *} \\
(0.0014)\end{array}$ \\
\hline Degree & $\begin{array}{c}0.027^{* * *} \\
(0.0044)\end{array}$ & $\begin{array}{c}0.028^{* * *} \\
(0.0038)\end{array}$ & $\begin{array}{c}0.13^{* * *} \\
(0.018)\end{array}$ \\
\hline WrkSup & $\begin{array}{l}0.032^{* * *} \\
(0.0095)\end{array}$ & $\begin{array}{c}0.031^{* * *} \\
(0.0093)\end{array}$ & $\begin{array}{r}0.17^{* * *} \\
(0.041)\end{array}$ \\
\hline FirmOwn & $\begin{array}{l}0.0084 \\
(0.030)\end{array}$ & $\begin{array}{l}0.0067 \\
(0.028)\end{array}$ & $\begin{array}{l}0.073 \\
(0.13)\end{array}$ \\
\hline RelIncome & $\begin{array}{l}0.029^{* * *} \\
(0.0061)\end{array}$ & $\begin{array}{c}0.029^{* * *} \\
(0.0065)\end{array}$ & $\begin{array}{l}0.14^{* * *} \\
(0.030)\end{array}$ \\
\hline Cosmopol & $\begin{array}{l}0.036^{* * *} \\
(0.0040)\end{array}$ & $\begin{array}{c}0.035^{* * *} \\
(0.0036)\end{array}$ & $\begin{array}{r}0.17^{* * *} \\
(0.017)\end{array}$ \\
\hline $\begin{array}{r}\text { Country fixed } \\
\text { effects }\end{array}$ & yes & yes & yes \\
\hline Constant & $\begin{array}{c}0.25^{* * *} \\
(0.023)\end{array}$ & & \\
\hline Cut1 & & & $\begin{array}{c}1.23^{* * *} \\
(0.11)\end{array}$ \\
\hline Cut2 & & & $\begin{array}{c}2.41^{* * *} \\
(0.11)\end{array}$ \\
\hline $\begin{array}{r}\text { Observations } \\
\text { R2 }\end{array}$ & $\begin{array}{c}25,673 \\
0.085\end{array}$ & 25,673 & 25,673 \\
\hline $\begin{array}{r}\text { Pseudo R2 } \\
\% \text { correctly predicted }\end{array}$ & & $\begin{array}{c}0.0659 \\
64.89\end{array}$ & 0.0540 \\
\hline
\end{tabular}

Robust standard errors clustered at the country level in parentheses

*** $\mathrm{p}<0.01, * * \mathrm{p}<0.05, * \mathrm{p}<0.1$

Table 1: Estimation results for individual determinants

Walker (2012) and is in line with predictions from economic theory on actual distributional effects of FDI, as discussed above.

Because the composition of populations with respect to individuals' socioeconomic characteristics is likely to differ across countries, our findings might explain the large cross-country differences in indivdiuals' average attitude towards MNEs. It could, for example, be that some countries are, on average, less hostile towards FDI because they have a younger, or better educated, population. However, this does not appear to be the case. Table 2 reports the results on the country dummies from regression (1), that were supressed in table 1 . We see that, even after controlling for individual characteristics, the estimated country fixed effects vary sigificantly across countries. The fixed effects are based on the estimation of equation (1) and all numbers are expressed relative to the USA. The United States are a 
natural reference country and also show an intermediate average attitude towards FDI.

\begin{tabular}{|c|c|c|c|c|c|c|c|}
\hline & (1) & (2) & (3) & & (1) & (2) & (3) \\
\hline VARIABL. & $\begin{array}{c}\text { OLS } \\
\text { MNE-PHIL }\end{array}$ & $\begin{array}{c}\text { Logit } \\
\text { MNE-PHIL }\end{array}$ & $\begin{array}{l}\text { OLogit } \\
\text { MNE-ATT }\end{array}$ & $\begin{array}{l}\text { VARIABL. } \\
\text { (CONT'D) }\end{array}$ & $\begin{array}{c}\text { OLS } \\
\text { MNE-PHIL }\end{array}$ & $\begin{array}{c}\text { Logit } \\
\text { MNE-PHIL }\end{array}$ & $\begin{array}{c}\text { OLogit } \\
\text { MNE-ATT }\end{array}$ \\
\hline $\begin{array}{r}\text { Individual } \\
\text { controls }\end{array}$ & yes & yes & yes & dum_KOR & $\begin{array}{l}0.11^{* * *} \\
(0.0045)\end{array}$ & $\begin{array}{c}0.097^{* * *} \\
(0.0042)\end{array}$ & $\begin{array}{l}0.43^{* * *} \\
(0.018)\end{array}$ \\
\hline dum_NOR & $\begin{array}{c}0.12^{* * *} \\
(0.0032)\end{array}$ & $\begin{array}{c}0.11^{* * *} \\
(0.0031)\end{array}$ & $\begin{array}{c}0.46^{* * *} \\
(0.014)\end{array}$ & dum_CZE & $\begin{array}{c}-0.063^{* * *} \\
(0.0080)\end{array}$ & $\begin{array}{c}-0.060^{* * *} \\
(0.0073)\end{array}$ & $\begin{array}{c}-0.24 * * * \\
(0.034)\end{array}$ \\
\hline dum_CHE & $\begin{array}{c}-0.028 * * * \\
(0.0083)\end{array}$ & $\begin{array}{c}-0.026^{* * *} \\
(0.0079)\end{array}$ & $\begin{array}{c}0.023 \\
(0.034)\end{array}$ & dum_HUN & $\begin{array}{l}-0.10^{* * *} \\
(0.0089)\end{array}$ & $\begin{array}{l}-0.10^{* * *} \\
(0.0080)\end{array}$ & $\begin{array}{c}-0.48^{* * *} \\
(0.038)\end{array}$ \\
\hline dum_IRL & $\begin{array}{c}0.12^{* * *} \\
(0.0056)\end{array}$ & $\begin{array}{c}0.11^{* * *} \\
(0.0050)\end{array}$ & $\begin{array}{l}0.83^{* * *} \\
(0.023)\end{array}$ & dum_SVK & $\begin{array}{c}-0.094 * * * \\
(0.0072)\end{array}$ & $\begin{array}{c}-0.092^{* * *} \\
(0.0067)\end{array}$ & $\begin{array}{c}-0.45^{* * *} \\
(0.032)\end{array}$ \\
\hline dum_DNK & $\begin{array}{l}0.12^{* * *} \\
(0.0031)\end{array}$ & $\begin{array}{c}0.11^{* * * *} \\
(0.0028)\end{array}$ & $\begin{array}{l}0.64 * * * \\
(0.015)\end{array}$ & dum_RUS & $\begin{array}{c}-0.074 * * * \\
(0.0039)\end{array}$ & $\begin{array}{c}-0.072^{* * *} \\
(0.0036)\end{array}$ & $\begin{array}{c}-0.24 * * * \\
(0.017)\end{array}$ \\
\hline dum_NLD & $\begin{array}{l}0.15^{* * *} \\
(0.0070)\end{array}$ & $\begin{array}{l}0.14^{* * *} \\
(0.0064)\end{array}$ & $\begin{array}{c}0.62^{* * *} \\
(0.027)\end{array}$ & dum_CHL & $\begin{array}{c}-0.093^{* * *} \\
(0.0071)\end{array}$ & $\begin{array}{c}-0.098^{* * *} \\
(0.0062)\end{array}$ & $\begin{array}{c}-0.35^{* * *} \\
(0.031)\end{array}$ \\
\hline dum_CAN & $\begin{array}{l}-0.0034 \\
(0.0041)\end{array}$ & $\begin{array}{l}-0.0017 \\
(0.0040)\end{array}$ & $\begin{array}{l}-0.0043 \\
(0.017)\end{array}$ & dum_POL & $\begin{array}{c}-0.060^{* * * *} \\
(0.0068)\end{array}$ & $\begin{array}{c}-0.058^{* * *} \\
(0.0063)\end{array}$ & $\begin{array}{c}-0.26 * * * \\
(0.029)\end{array}$ \\
\hline dum_AUS & $\begin{array}{l}-0.13^{* * *} \\
(0.0046)\end{array}$ & $\begin{array}{c}-0.15^{* * *} \\
(0.0038)\end{array}$ & $\begin{array}{c}-0.66 * * * \\
(0.017)\end{array}$ & dum_LVA & $\begin{array}{c}-0.091^{* * *} \\
(0.0055)\end{array}$ & $\begin{array}{c}-0.090^{* * *} \\
(0.0052)\end{array}$ & $\begin{array}{c}-0.41^{* * *} \\
(0.025)\end{array}$ \\
\hline dum_SWE & $\begin{array}{l}0.18^{* * *} \\
(0.0060)\end{array}$ & $\begin{array}{c}0.16 * * * \\
(0.0056)\end{array}$ & $\begin{array}{c}0.58^{* * *} \\
(0.024)\end{array}$ & dum_VEN & $\begin{array}{c}0.12^{* * *} \\
(0.0082)\end{array}$ & $\begin{array}{c}0.12 * * * \\
(0.0074)\end{array}$ & $\begin{array}{l}1.11 * * * \\
(0.034)\end{array}$ \\
\hline dum_DEUW & $\begin{array}{l}0.075^{* * *} \\
(0.0095)\end{array}$ & $\begin{array}{l}0.071^{* * *} \\
(0.0085)\end{array}$ & $\begin{array}{l}0.40^{* * *} \\
(0.037)\end{array}$ & dum_URY & $\begin{array}{l}-0.14^{* * *} \\
(0.0077)\end{array}$ & $\begin{array}{l}-0.15^{* * *} \\
(0.0069)\end{array}$ & $\begin{array}{c}-0.64^{* * *} \\
(0.034)\end{array}$ \\
\hline dum_DEUE & $\begin{array}{c}0.093^{* * *} \\
(0.0094)\end{array}$ & $\begin{array}{c}0.088^{* * *} \\
(0.0084)\end{array}$ & $\begin{array}{c}0.42^{* * *} \\
(0.037)\end{array}$ & dum_BGR & $\begin{array}{l}0.066^{* * *} \\
(0.0062)\end{array}$ & $\begin{array}{c}0.062^{* * *} \\
(0.0057)\end{array}$ & $\begin{array}{c}0.42^{* * *} \\
(0.025)\end{array}$ \\
\hline dum_FIN & $\begin{array}{l}0.093^{* * *} \\
(0.0044)\end{array}$ & $\begin{array}{c}0.086^{* * *} \\
(0.0038)\end{array}$ & $\begin{array}{c}0.43^{* * *} \\
(0.017)\end{array}$ & dum_PHL & $\begin{array}{l}0.072^{* * *} \\
(0.0053)\end{array}$ & $\begin{array}{c}0.067^{* * *} \\
(0.0048)\end{array}$ & $\begin{array}{l}0.37^{* * *} \\
(0.021)\end{array}$ \\
\hline dum_FRA & $\begin{array}{l}-0.19^{* * *} \\
(0.0055)\end{array}$ & $\begin{array}{l}-0.21^{* * * *} \\
(0.0051)\end{array}$ & $\begin{array}{l}-0.92^{* * * *} \\
(0.026)\end{array}$ & Constant & $0.25^{* * *}$ & & \\
\hline $\begin{array}{l}\text { dum_GBR } \\
\text { dum_JPN }\end{array}$ & $\begin{array}{c}-0.0013 \\
(0.0067) \\
0.15^{* * *}\end{array}$ & $\begin{array}{c}-0.0019 \\
(0.0061) \\
0.14^{* * *}\end{array}$ & $\begin{array}{c}-0.079^{* * *} \\
(0.027) \\
0.73^{* * *}\end{array}$ & Cut1 & $(0.023)$ & & $\begin{array}{c}1.23^{* * *} \\
(0.11)\end{array}$ \\
\hline $\begin{array}{l}\text { dum_ESP } \\
\text { dum_NZL }\end{array}$ & $\begin{array}{c}(0.0042) \\
-0.022^{* *} \\
(0.0099) \\
0.14^{* * *} \\
(0.0095)\end{array}$ & $\begin{array}{c}(0.0034) \\
-0.021^{* *} \\
(0.0087) \\
0.14^{* * *} \\
(0.0080)\end{array}$ & $\begin{array}{c}(0.018) \\
-0.093^{* *} \\
(0.041) \\
0.57^{* * *} \\
(0.035)\end{array}$ & Cut 2 & & & $\begin{array}{c}2.41^{* * *} \\
(0.11)\end{array}$ \\
\hline dum_PRT & $\begin{array}{c}-0.15^{* * *} \\
(0.010)\end{array}$ & $\begin{array}{c}-0.16^{* * *} \\
(0.0089)\end{array}$ & $\begin{array}{c}-0.68^{* * *} \\
(0.043)\end{array}$ & $\begin{array}{r}\text { Observations } \\
\mathrm{R} 2\end{array}$ & $\begin{array}{c}25,673 \\
0.085\end{array}$ & 25,673 & 25,673 \\
\hline dum_SVN & $\begin{array}{l}0.029^{* * *} \\
(0.0084)\end{array}$ & $\begin{array}{c}0.027^{* * *} \\
(0.0076)\end{array}$ & $\begin{array}{c}0.20^{* * *} \\
(0.033)\end{array}$ & $\begin{array}{l}\text { Pseudo R2 } \\
\text { \% correctly }\end{array}$ & & $\begin{array}{c}0.0659 \\
64.89\end{array}$ & 0.0540 \\
\hline dum_ISRJ & $\begin{array}{l}0.18^{* * *} \\
(0.0039)\end{array}$ & $\begin{array}{l}0.16^{* * *} \\
(0.0036)\end{array}$ & $\begin{array}{l}0.82^{* * *} \\
(0.020)\end{array}$ & predicted & & & \\
\hline
\end{tabular}

Robust standard errors clustered at the country level in parentheses

${ }^{* * *} \mathrm{p}<0.01,{ }^{* *} \mathrm{p}<0.05, * \mathrm{p}<0.1$

Table 2: Estimated country fixed effects (cont'd from table 1)

Figure 2 depicts the coefficients of the country dummies next to the average country answer for the same countries as before ${ }^{6}$ We see that controlling for individual characteristics changes the remaining average answer. Individual characteristics thus matter for countries' average attitude towards FDI. Countries like Latvia or Slovakia show an even stronger country-specific resentment towards FDI when we account for the socioeconomic composition of these countries in the sample, whereas for Great Britain and New Zealand we observe the opposite. However, although the standard deviation of average answers slightly decreases for the whole sample when we control for individual characteristics, it is only slightly lower when we do so (0.1096) than when we don't (0.1110). The remaining (significant, as table 2 shows) variation between countries in average revealed attitudes to-

\footnotetext{
${ }^{6}$ The regression run for that purpose uses the de-meaned (relative to the sample means) individual characteristics as explanatory variables and adds the size of the US fixed effect. This simply shifts up the estimated coefficients for the country dummies compared to those reported in table 2 but does not affect their differences, and is done in order to make the numbers comparable.
} 
wards FDI could be due to cultural differences, either in economic attitudes or in answering surveys.7 But it could also reflect the fact that the economic and social environment of a person influences the effects of FDI and therefore the attitude towards MNEs, which is what we will test for in the next section.

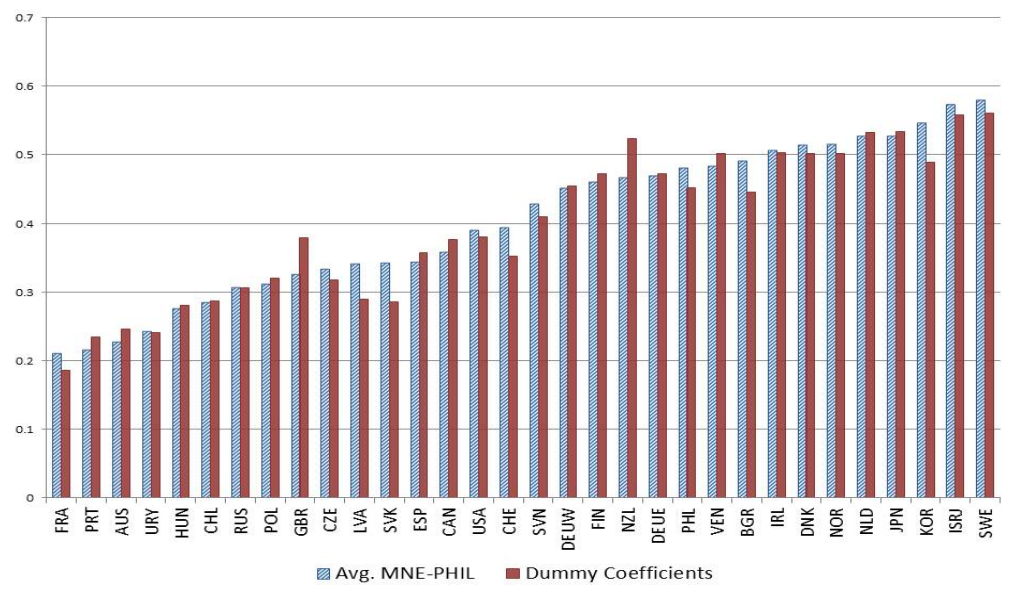

Figure 2: Average value of MNE-PHIL and estimated country fixed effects from regression on demeaned individual characteristics.

\section{Why do attitudes towards MNEs differ across coun- tries?}

Different economic and social environments may attract different types of FDI, and in different environments the effects of MNEs on individuals' prosperity and well-being may therefore vary. Moreover, the perceptions of distributional effects of FDI and of the role of MNEs may depend on the environment. Based on these observations, we will test the influence of parameters that characterize the macroeconomic and social environment on respondents' attitudes towards FDI. We hence replace the country dummies in regression (1) by country-level characteristics and estimate the following regression:

$$
M N E-P H I L_{i c}=\boldsymbol{\beta}_{\mathbf{1}}^{\prime} \boldsymbol{X}_{i \boldsymbol{c}}+\boldsymbol{\beta}_{\mathbf{2}}^{\prime} \boldsymbol{Z}_{\boldsymbol{c}}+\epsilon_{i c}
$$

The variables in vector $Z_{c}$ represent country-level variables of interest. 8 For all these

\footnotetext{
${ }^{7}$ This seems to be the implicit assumption of Kaya and Walker (2012). They do not control for the patriotism of individuals and hence furthermore ascribe this effect to country-varying cosmopolitan attitudes.

${ }^{8}$ Most of these regressors are retrieved from the World Bank's World Development Indicators. A detailed
} 
variables, we take the average over the 5 -year period before the survey was conducted, i.e. 1999-2003, as this period should be most influential in shaping individuals' attitudes.

Kose et al. (2009) point out that the effects of financial globalization, and FDI in particular, in developing and emerging economies may differ from those in developed economies. Thus, we include the $\log$ of per capita GDP (GDP p.c.) as a natural explanatory variable in our regression. A high degree of income inequality could also affect how the presence of MNEs is perceived. We therefore use countries' Gini-coefficient as an additional regressor (GINI). People's actual exposure to multinational enterprises may also influence their perspective on FDI, so we include the average inward FDI stock in a country divided by GDP (FDIStock). FDI that focuses on resource extraction is likely to be rather non-inclusive and generate discontent within the population. On the other hand, primary sector investment has the potential of facilitating technological cooperation and hence increasing the economic possibilities of recipient economies. Because data on sectoral FDI is only selectively available, we proxy for the extent of extractive FDI by using the share of fuel exports and ore exports, respectively, in countries' overall exports (FuelExp, OreExp). As argued by Arteta et al. (2001), countries that are open to international trade are more likely to benefit from FDI. We measure de facto trade openness by the average ratio of imports plus exports divided by GDP (TradeOpen). The empirical literature furthermore emphasizes the role of capital market development for a country's ability to reap gains from FDI (e.g. Bailliu, 2000, Edwards, 2001). The value of stocks publicly traded as a share of GDP gives us an indicator for a country's financial depth and capital market development (CapDev). Another effect that is emphasized by the literature on FDI and growth is that foreign firms bring advanced technologies into the receiving country (see Harrison and Rodríguez-Clare, 2010, for an overview). We therefore conjecture that countries which are less developed in terms of total factor productivity have more potential to benefit from FDI. For this reason, we also include a measure of countries' TFP relative to that of the Unites States (TFP).

In addition to the economic environment, social and institutional factors are likely to influence the growth effects of FDI (see, e.g., Bussiere and Fratzscher, 2008) and may also determine how the distributional consequences of FDI are evaluated. Our first candidate for this is corruption: in countries that are characterized by rampant corruption, the benefits from FDI are likely to be reserved to a small elite. To test whether this affects respondents' view on multinational enterprises, we use the index of perceived corruption published by Transparency International (Corr), which ranges from 0 to 10, with a value of 0 reflecting an extreme degree of corruption and a score of 10 reflecting the (perceived) absence of corruption. In a similar fashion, the extent of direct democratic control over political instilist of variable definitions and sources is provided in the Appendix. 
tutions could have an influence. To test for this, we use an index provided by the Polity IV Project (polity 2), evaluating the level of democracy in a country on a scale from -10 to 10 (Democ). Finally, we use the KOF indices of "political and social globalization" (Dreher, 2006), which indicate by how much countries are integrated into formal and informal networks of cultural, social and political exchange. The KOF indices range from 0 to 100, with 100 being the highest possible level of political and social globalization. We conjecture that individuals in countries that are more "politically and socially globalized", as reflected by PolGlob and SocGlob, adopt a more favorable view on multinational enterprises. ? $^{9}$ A table of all country-level variables used, including scaling and sources, is found in table 11, summary statistics are depicted in table 12 , both are listed in appendix A.

The elements of $\boldsymbol{\beta}_{\mathbf{2}}$ indicate by how much a difference in a country-specific variable shifts the probability that a person views FDI rather positively, compared to a person with the same socioeconomic characteristics in another country. The country-specific variables $\boldsymbol{Z}_{\boldsymbol{c}}$ are, of course, identical for all respondents in one country, but we run regression (2) on all individual observations. In such a multilevel analysis with many per-group observations and relatively few groups the standard errors would be biased downward without clustering. It should, however, be kept in mind that variation in country-level variables comes from only a rather small set of countries 10

Table 3 shows the estimation results for the country specific variables. The level of income has slightly positive, albeit insignificant, coefficients in all estimations. Inequality, by contrast, has a significant negative effect on the average perception of FDI. The de-facto exposure to FDI does not seem to significantly influence whether a person has a more positive picture of FDI, although the coefficients are positive. Living in a country that is an exporter of raw materials significantly affects the perspectives on FDI. However, this goes only partially in the direction that one would expect. In fuel-exporting countries, people seem to view FDI rather positively. In ore-exporting countries, by contrast, respondents have a more critical view of multinational corporations. These results are not driven by particular countries, but remain valid when we exclude those countries from the sample that rely most heavily on raw material exports. Trade openness and total factor productivity exhibit the expected positive effect, but their coefficients are not statistically significant. The level of capital market development in a country, by contrast, significantly affects how FDI is perceived. This is in line with the argument that a certain level of financial depth is

\footnotetext{
${ }^{9}$ Interestingly, the KOF indices are not strongly correlated at the country level, with the correlation between both measures amounting to a mere 0.47 . Generally, more geographically remote countries (e.g. Japan, Chile) tend to be less socially globalized than politically.

${ }^{10}$ As highlighted by Bryan and Jenkins (2013), our regression closely resembles a regression of the dummies from regression (1) on country-specific variables, using a sample of as many observations as there are groups/countries.
} 


\begin{tabular}{|c|c|c|c|c|c|c|c|}
\hline & (1) & $(2)$ & (3) & & (1) & $(2)$ & (3) \\
\hline VARIABLES & $\begin{array}{c}\text { OLS } \\
\text { MNE-PHIL }\end{array}$ & $\begin{array}{c}\text { Logit } \\
\text { MNE-PHIL }\end{array}$ & $\begin{array}{c}\text { OLogit } \\
\text { MNE-ATT }\end{array}$ & $\begin{array}{r}\text { VARIABLES } \\
(\text { CONT'D) }\end{array}$ & $\begin{array}{c}\text { OLS } \\
\text { MNE-PHIL }\end{array}$ & $\begin{array}{c}\text { Logit } \\
\text { MNE-PHIL }\end{array}$ & $\begin{array}{c}\text { OLogit } \\
\text { MNE-ATT }\end{array}$ \\
\hline $\begin{array}{r}\text { Individual } \\
\text { controls }\end{array}$ & yes & yes & yes & Democ & $\begin{array}{l}-0.012 \\
(0.023)\end{array}$ & $\begin{array}{l}-0.012 \\
(0.024)\end{array}$ & $\begin{array}{c}-0.068 \\
(0.11)\end{array}$ \\
\hline GDP p.c. & $\begin{array}{l}-0.0060 \\
(0.060)\end{array}$ & $\begin{array}{r}-0.0047 \\
(0.060)\end{array}$ & $\begin{array}{l}0.070 \\
(0.28)\end{array}$ & PolGlob & $\begin{array}{c}-0.0028 \\
(0.0021)\end{array}$ & $\begin{array}{c}-0.0028 \\
(0.0020)\end{array}$ & $\begin{array}{c}-0.012 \\
(0.0097)\end{array}$ \\
\hline GINI & $\begin{array}{c}-0.81^{* *} \\
(0.35)\end{array}$ & $\begin{array}{c}-0.77^{* *} \\
(0.36)\end{array}$ & $\begin{array}{l}-3.07^{*} \\
(1.69)\end{array}$ & SocGlob & $\begin{array}{c}-0.0079 * * * \\
(0.0014)\end{array}$ & $\begin{array}{c}-0.0076^{* * *} \\
(0.0014)\end{array}$ & $\begin{array}{c}-0.037 * * * \\
(0.0071)\end{array}$ \\
\hline FDIStock & $\begin{array}{c}0.12 \\
(0.10) \\
0.2 * *\end{array}$ & $\begin{array}{c}0.11 \\
(0.11)\end{array}$ & $\begin{array}{c}0.81 \\
(0.54)\end{array}$ & Constant & $1.09 *$ & & \\
\hline FuelExp & $\begin{array}{l}0.22^{* *} \\
(0.086)\end{array}$ & $\begin{array}{c}0.22^{* *} \\
(0.086)\end{array}$ & $\begin{array}{c}1.09^{* *} \\
(0.49)\end{array}$ & Cut1 & $(0.59)$ & & -1.82 \\
\hline OreExp & $\begin{array}{c}-0.50 * * \\
(0.19)\end{array}$ & $\begin{array}{c}-0.52^{* * *} \\
(0.19)\end{array}$ & $\begin{array}{c}-2.78 * * * \\
(0.95)\end{array}$ & Cut 2 & & & $\begin{array}{l}(2.75) \\
-0.66\end{array}$ \\
\hline TradeOpen & $\begin{array}{c}0.095 \\
(0.086)\end{array}$ & $\begin{array}{c}0.098 \\
(0.085)\end{array}$ & $\begin{array}{c}0.38 \\
(0.40)\end{array}$ & & & & $(2.76)$ \\
\hline CapDev & $\begin{array}{c}0.058 * * \\
(0.028)\end{array}$ & $\begin{array}{c}0.056^{* *} \\
(0.028)\end{array}$ & $\begin{array}{c}0.20 \\
(0.13)\end{array}$ & $\begin{array}{r}\text { Observations } \\
\mathrm{R} 2\end{array}$ & $\begin{array}{c}25,673 \\
0.069\end{array}$ & 25,673 & 25,673 \\
\hline TFP & $\begin{array}{c}-0.075 \\
(0.083) \\
0.053^{* * *} \\
(0.012)\end{array}$ & $\begin{array}{c}-0.078 \\
(0.083) \\
0.053^{* * *} \\
(0.012)\end{array}$ & $\begin{array}{c}-0.46 \\
(0.43) \\
0.23^{* * *} \\
(0.054)\end{array}$ & $\begin{array}{r}\text { Pseudo R2 } \\
\% \text { correctly } \\
\text { predicted }\end{array}$ & & $\begin{array}{c}0.0526 \\
64.26\end{array}$ & 0.0424 \\
\hline
\end{tabular}

Robust standard errors clustered at the country level in parentheses

$* * * \mathrm{p}<0.01, * * \mathrm{p}<0.05, * \mathrm{p}<0.1$

Table 3: Estimation results for country level determinants

Full regression table in table 13

required in order for economic agents to be able to obtain gains from the presence of MNEs, e.g. via spillover effects, or simply by taking part in increased economic activity. Only for the ordered logit regression on MNE-ATT, the effect is not statistically significant, albeit still positive.

For the institutional and societal variables, the absence of corruption, as indicated by a high value of the TI index, does contribute to a more positive view of the role of MNEs. However, for democracy, the picture is not as expected. The point estimates show a negative sign, although insigificant. Surprisingly, the levels of social and political globalization in a country have a negative effect on the attitude towards MNEs, and for social globalization, the coefficient is highly statistically significant. This result is robust to excluding subcategories of the KOF social globalization indices - for example those that measure the prevalence of famous international brands in an economy. This is a puzzling, yet interesting result that deserves further investigation.

We conclude that macroeconomic variables and those of the institutional/societal environment do influence country-specific perspectives of FDI. Many - but not all - do so in the directions which would be predicted on theoretical or empirical grounds. Note, finally, that the effects of the individual determinants are not affected by the inclusion of macroeconomic variables. The full regression table that also displays the coefficients of individual characteristics is provided in appendix $\mathrm{B}$, table 13 . 


\section{5 (How) do marginal effects of individual characteristics differ across countries?}

In this section, we explore whether the socio-economic environment not only affects the overall attitude towards MNEs in a country, but also shapes the perceived distributional effects of FDI at the individual level. If the environment determines which agents potentially benefit and lose from the presence of multinational enterprises, this should - regarding our previous results - be reflected by relative individual attitudes towards these. To identify the impact of aggregate variables on the marginal impact of socio-economic characteristics, we therefore interact individual-specific with country-specific data.

We start by testing a central implication of the neoclassical model: since capital is relatively scarce in developing countries, returns are high and capital should move there from developed countries. This raises the overall income in the receiving country, but reduces returns to capital that is already in place, i.e. for entrepreneurs. The opposite effect should be visible in capital-abundant developed countries. Capital moving away harms jobs and wages, whereas capital owners should profit from better investment possibilities abroad. Based on these considerations, we will test whether entrepreneurs perceive the role of MNEs more positively in rich countries. To this end, we interact the dummy variable that indicates whether a person is a capital owner with his or her country's per capita GDP (in logs). This results in the following regression equation:

$$
M N E-P H I L_{i c}=\boldsymbol{\beta}_{\mathbf{1}}^{\prime} \boldsymbol{X}_{\boldsymbol{i c}}+\boldsymbol{\beta}_{\mathbf{2}}^{\prime} \boldsymbol{Z}_{\boldsymbol{c}}+\beta_{3} Y_{i c}+\epsilon_{i c}
$$

where $\beta_{3}$ is the coefficient on the interacted variable of the firm-owner-dummy with (log of) GDP per capita. All other variables, both individual and at the country level, are still included as regressors. In order to ease the interpretation of the sign ands size of coefficients for interacted variables, which is problematic in logit and ordered logit models, we restrict ourselves to the linear probabilty model in this section. The results of the above regression for the variables of interest is reported in column 1 of table 4 . The full regression result is, again, found in appendix B, table 14 .

Inspecting the signs of the respective coefficients supports our hypothesis: the direct effect of being an entrepreneur on the attitude towards FDI is negative, but it becomes more positive as per-capita GDP increases (the interaction term). This implies that in poorer (i.e. capital-scarce) countries, firm owners do not like FDI, but they tend to like it more in richer (capital-abundant) countries. Focusing on our sample, we find that the total effect of beeing a firm owner is significantly negative at the 25\%-quantile of GDP per capita (a country like Poland), but significantly positive at the 75\%-quantile (a country like Germany). Thus, 
owning a firm increases the likelihood of being in favor of FDI in rich countries, but reduces it in poorer countries.

Another personal characteristic whose influence on the attitude towards FDI possibly depends on country-specific variables is agents' educational attainment: Whereas poorer countries are more likely to attract vertical FDI, richer countries experience higher shares of horizontal FDI.11 Different types of investment are likely to be associated with different demands for various skills, with horizontal FDI increasing the demand for high-skilled workers and vertical FDI increasing the demand for low-skilled workers. Moreover, MNEs facilitate trade and reduce trade costs. If trade is driven by relative factor endowments (and hence investment by the respective factor's relatively lower price), Stolper-Samuelson effects increase the real wage for low-skilled labor in poorer, low-skill abundant countries and the

\footnotetext{
${ }^{11}$ Yeaple (2003) and Hanson et al. (2005) show how this drives investment decisions on the company level. The argument is captured in the disussion around the so-called Knowledge-Capital model (as empirically treated in e.g. Carr et al. 2001 and Davies, 2008).
}

\begin{tabular}{rccc}
\hline & $(1)$ & $(2)$ & $(3)$ \\
\hline VARIABLES & OLS & OLS & OLS \\
\hline Degree & $0.026^{* * *}$ & MNE-PHIL & MNE-PHIL \\
& $(0.0051)$ & $-0.16^{* * *}$ & $-0.16^{* * *}$ \\
FirmOwn & $-1.48^{* * *}$ & $(0.045)$ & $(0.045)$ \\
& $(0.53)$ & 0.023 & $-1.36^{* *}$ \\
Individual & yes & $(0.031)$ & $(0.52)$ \\
controls & -0.0063 & yes & yes \\
GDP p.c. & $(0.060)$ & -0.060 & -0.060 \\
& yes & $(0.060)$ & $(0.060)$ \\
Country level & $0.15^{* * *}$ & yes & yes \\
controls & $(0.053)$ & & $0.14^{* *}$ \\
FirmOwn \# & & $0.019^{* * *}$ & $(0.053)$ \\
GDP p.c. & & $(0.0046)$ & $0.018^{* * *}$ \\
Degree \# & $1.09^{*}$ & $1.69^{* * *}$ & $(0.0046)$ \\
GDP p.c. & $(0.59)$ & $(0.59)$ & $1.68^{* * *}$ \\
Constant & 25,673 & 25,673 & $(0.59)$ \\
& 0.069 & 0.070 & 25,673 \\
Observations & R2 & & 0.070 \\
\hline
\end{tabular}

Robust standard errors clustered at the country level in parentheses

*** $\mathrm{p}<0.01,{ }^{* *} \mathrm{p}<0.05,{ }^{*} \mathrm{p}<0.1$

Table 4: Estimation results of interaction terms

Full regression table in table 14 
real wage of high-skilled labor in richer, high-skill abundant countries ${ }^{12}$ The respective skill group is then also the one likely to benefit from FDI. Note that these arguments contrast with an alternative understanding of FDI, according to which North-South FDI increases the demand for skilled labor both in the North and in the South by extending the range of products produced with greater skill intensity in both countries, and hence unanimously will lead to an increase in the skill wage gap (Feenstra and Hanson, 1997) To test whether the influence of a person's skill level on his or her attitude towards multinational enterprises differs between rich and poor countries, we interact the educational Degree of a person with per-capita GDP. Given the discussion above, if the differentiated effect is present, we expect a positive sign for the interaction term.

The results of this exercise are shown in column 2 of table 4 . They give strong support to the hypothesis that the effect of FDI on a particular skill group depends on the host country's per-capita income: not only is the interaction term significantly positive, such that the effect of a greater skill level on a favorable attitude increases with the respondent's country's per capita GDP, but the positive sign for Degree itself even turns negative. This change in sign of the effect of Degree again happens within relevant values of GDP p.c.: when evaluating the overall effect of skill level at the $25 \%$ - and $75 \%$-quantiles of GDP per capita in our sample, it is indeed negative in the former and positive in the latter. This supports the hypothesis that FDI is seen more negatively by higher skill classes in poorer countries, whereas in rich countries, being a relatively high skilled worker leads to a more favorable attitude towards FDI. Hence individual attitudes are in line with arguments that predict differentiated effects of FDI on skill classes between countries. Column 3 of table 4 shows that the previous results still hold when both interaction variables are included in one regression.

\section{$6 \quad$ Extensions and robustness checks}

This section explores some extensions of the above analysis and tests whether our results are robust to alternative specifications. More specifically, we use a different definition of our dependent variable, control for the attitude towards free trade, weigh the observations to correct for sample composition, and use measures of factor abundance instead of per-capita GDP when computing interaction terms. For means of exposition, we run one robustness test at a time.

\footnotetext{
${ }^{12}$ Romalis (2004) and Morrow (2010) confirm the empirical relevance of the Heckscher-Ohlin model and show that trade is rather driven by differences in endowments of high-skilled and low-skilled labor. For a discussion how this combines with international investment, see Ortseifer and Schwab (2015).
} 


\section{Narrow definition of MNE-PHIL}

So far, our dependent variable defined someone as having a positive attitude towards MNEs if he or she did not agree with the critical statement about MNEs. Hence we interpreted those who "neither agree nor disagree" with the statement that large international companies do harm to local businesses as having a rather favorable view on FDI. In this subsection, we adopt a narrower definition, by only defining those as viewing FDI positively that actively disagree or strongly disagree with the statement. We denote this new dummy variable as MNE-PHIL $_{\text {Active }}$ and run regressions of type (1), (2), and (3) using it as a regressand. For ease of exposition, we only report the estimations of the LPM regressions in the text. The results are shown in table 5. The full regression table can again be found in appendix B, table 1513

\begin{tabular}{|c|c|c|c|c|c|c|c|c|c|}
\hline & (1) & (2) & (3) & (4) & & (1) & (2) & (3) & (4) \\
\hline VARIABL. & $\begin{array}{c}\text { OLS } \\
\text { MNE- } \\
\text { PHIL }_{\text {Act }}\end{array}$ & $\begin{array}{c}\text { OLS } \\
\text { MNE- } \\
\text { PHIL }_{\text {Act }}\end{array}$ & $\begin{array}{c}\text { OLS } \\
\text { MNE- }_{\text {PHIL }_{\text {Act }}}\end{array}$ & $\begin{array}{c}\text { OLS } \\
\text { MNE- } \\
\text { PHIL }_{\text {Act }}\end{array}$ & $\begin{array}{l}\text { VARIABL. } \\
\text { (CONT'D) }\end{array}$ & $\begin{array}{c}\text { OLS } \\
\text { MNE- } \\
\text { PHIL }_{\text {Act }}\end{array}$ & $\begin{array}{c}\text { OLS } \\
\text { MNE- } \\
\text { PHIL }_{\text {Act }}\end{array}$ & $\begin{array}{c}\text { OLS } \\
\text { MNE- } \\
\text { PHIL }_{\text {Act }}\end{array}$ & $\begin{array}{c}\text { OLS } \\
\text { MNE- } \\
\text { PHIL }_{\text {Act }}\end{array}$ \\
\hline Male & $\begin{array}{c}0.034^{* * *} \\
(0.0064)\end{array}$ & $\begin{array}{c}0.039 * * * \\
(0.0068)\end{array}$ & $\begin{array}{c}0.040^{* * *} \\
(0.0065)\end{array}$ & $\begin{array}{c}0.038^{* * *} \\
(0.0064)\end{array}$ & TradeOpen & & $\begin{array}{c}0.033 \\
(0.067)\end{array}$ & $\begin{array}{c}0.033 \\
(0.067)\end{array}$ & $\begin{array}{c}0.031 \\
(0.067)\end{array}$ \\
\hline Age & $\begin{array}{c}-0.00066^{* * *} \\
(0.00024)\end{array}$ & $\begin{array}{c}-0.00076^{* * * *} \\
(0.00026)\end{array}$ & $\begin{array}{c}-0.00077^{* * *} \\
(0.00025)\end{array}$ & $\begin{array}{c}-0.00078^{* * *} \\
(0.00025)\end{array}$ & CapDev & & $\begin{array}{c}0.013 \\
(0.025)\end{array}$ & $\begin{array}{c}0.014 \\
(0.026)\end{array}$ & $\begin{array}{c}0.013 \\
(0.025)\end{array}$ \\
\hline Degree & $\begin{array}{l}0.020^{* * *} \\
(0.0042)\end{array}$ & $\begin{array}{c}0.020^{* * *} \\
(0.0044)\end{array}$ & $\begin{array}{c}0.020^{* * *} \\
(0.0043)\end{array}$ & $\begin{array}{c}-0.19^{* * *} \\
(0.042)\end{array}$ & TFP & & $\begin{array}{c}-0.12 \\
(0.095)\end{array}$ & $\begin{array}{c}-0.11 \\
(0.095)\end{array}$ & $\begin{array}{c}-0.11 \\
(0.093)\end{array}$ \\
\hline WrkSup & $\begin{array}{c}0.034^{* * *} \\
(0.0080)\end{array}$ & $\begin{array}{c}0.031 * * * \\
(0.0097)\end{array}$ & $\begin{array}{c}0.031^{* * *} \\
(0.0095)\end{array}$ & $\begin{array}{c}0.031^{* * *} \\
(0.0093)\end{array}$ & Corr & & $\begin{array}{c}0.029^{* * *} \\
(0.0092)\end{array}$ & $\begin{array}{c}0.028^{* * *} \\
(0.0093)\end{array}$ & $\begin{array}{l}0.028^{* * *} \\
(0.0090)\end{array}$ \\
\hline FirmOwn & $\begin{array}{c}0.021 \\
(0.025)\end{array}$ & $\begin{array}{c}0.033 \\
(0.024)\end{array}$ & $\begin{array}{l}-0.73^{*} \\
(0.41)\end{array}$ & $\begin{array}{c}0.034 \\
(0.024)\end{array}$ & Democ & & $\begin{array}{l}-0.016 \\
(0.020)\end{array}$ & $\begin{array}{l}-0.016 \\
(0.019)\end{array}$ & $\begin{array}{l}-0.022 \\
(0.019)\end{array}$ \\
\hline Relincome & $\begin{array}{l}0.024^{* * *} \\
(0.0053)\end{array}$ & $\begin{array}{l}0.024^{* * *} \\
(0.0050)\end{array}$ & $\begin{array}{c}0.024^{* * *} \\
(0.0050)\end{array}$ & $\begin{array}{c}0.025^{* * *} \\
(0.0049)\end{array}$ & PolGlob & & $\begin{array}{l}-0.0014 \\
(0.0017)\end{array}$ & $\begin{array}{l}-0.0014 \\
(0.0017)\end{array}$ & $\begin{array}{l}-0.0016 \\
(0.0017)\end{array}$ \\
\hline Cosmopol & $\begin{array}{c}0.025^{* * *} \\
(0.0028)\end{array}$ & $\begin{array}{c}0.025^{* * *} \\
(0.0039)\end{array}$ & $\begin{array}{c}0.024^{* * *} \\
(0.0038)\end{array}$ & $\begin{array}{c}0.025^{* * *} \\
(0.0037)\end{array}$ & SocGlob & & $\begin{array}{c}-0.0068^{* * *} \\
(0.0013)\end{array}$ & $\begin{array}{c}-0.0068^{* * *} \\
(0.0013)\end{array}$ & $\begin{array}{c}-0.0066^{* * *} \\
(0.0013)\end{array}$ \\
\hline $\begin{array}{r}\text { Country fixed } \\
\text { effects }\end{array}$ & yes & no & no & no & $\begin{array}{l}\text { FirmOwn \# } \\
\text { GDP p.c. }\end{array}$ & & & $\begin{array}{l}0.077^{*} \\
(0.041)\end{array}$ & \\
\hline GDP p.c. & & $\begin{array}{c}0.056 \\
(0.051)\end{array}$ & $\begin{array}{c}0.056 \\
(0.051)\end{array}$ & $\begin{array}{c}-0.0035 \\
(0.051)\end{array}$ & $\begin{array}{l}\text { Degree \# } \\
\text { GDP p.c. }\end{array}$ & & & & $\begin{array}{l}0.021 * * * \\
(0.0044)\end{array}$ \\
\hline GINI & & $\begin{array}{l}-0.33 \\
(0.28)\end{array}$ & $\begin{array}{l}-0.32 \\
(0.28)\end{array}$ & $\begin{array}{l}-0.35 \\
(0.27)\end{array}$ & & & & & \\
\hline FDIStock & & $\begin{array}{l}0.24^{* *} \\
(0.11)\end{array}$ & $\begin{array}{l}0.24^{* *} \\
(0.11)\end{array}$ & $\begin{array}{l}0.24^{* *} \\
(0.11)\end{array}$ & Constant & $\begin{array}{r}-0.0047 \\
(0.020)\end{array}$ & $\begin{array}{c}0.15 \\
(0.48)\end{array}$ & $\begin{array}{c}0.15 \\
(0.48)\end{array}$ & $\begin{array}{c}0.81 \\
(0.49)\end{array}$ \\
\hline FuelExp & & $0.19^{*}$ & $0.19^{*}$ & 0.17 & Obs & 25673 & 24890 & 25673 & 25.673 \\
\hline OreExp & & $\begin{array}{c}-0.52 * * * \\
(0.16)\end{array}$ & $\begin{array}{c}-0.52^{* * *} \\
(0.16)\end{array}$ & $\begin{array}{c}-0.52 * * * \\
(0.16)\end{array}$ & $\mathrm{R} 2$ & 0.085 & 0.064 & 0.064 & 0.065 \\
\hline
\end{tabular}

Table 5: Robustness test: MNE-PHIL Active Full regression table in table 15

We see that the results do not change, although some of the country level characteristics appear to be slightly less significant. In turn, the Male dummy now becomes positively significant in all specifications 14 More importantly, the results on the interacted variables remain valid also in this specification.

\footnotetext{
${ }^{13}$ The results do not change for the logit and ordered logit regressions. Compared to the results above, only the percent correctly predicted rises to about 0.8 , which is, however, not surprising, given the greater share of zeros for MNE-PHIL Active. $_{\text {. }}$

${ }^{14}$ Whether this result has an economic background or it is simply due to the fact that MNE-loving males are more prone to give a proactive statement, rather than a cautious one, is subject to interpretation.
} 


\section{Attitudes towards trade}

The way the statement on attitudes towards MNEs is framed in the survey, it could represent the general attitude towards globalization, rather than just their view of multinational enterprises. To avoid such a misinterpretation, we include the response to the following statement as an additional regressor: "Free trade leads to better products becoming avail-

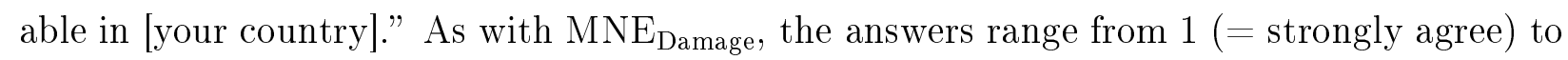
5 ( = strongly disagree). Hence a higher value of the variable Trade-Phob reflects a rather negative attitude towards international trade. Given that Trade-Phob more directly elicits the sentiment towards free trade, any difference between the agreements with the two statements should even more precisely depict the particular view on the special role of companies' presence. The results are given in table 6 .

\begin{tabular}{|c|c|c|c|c|c|c|c|c|c|}
\hline & (1) & (2) & (3) & (4) & & (1) & (2) & (3) & (4) \\
\hline & OLS & OLS & OLS & OLS & & OLS & OLS & OLS & OLS \\
\hline VARIABL. & $\begin{array}{l}\text { MNE- } \\
\text { PHIL }\end{array}$ & $\begin{array}{l}\text { MNE- } \\
\text { PHIL }\end{array}$ & $\begin{array}{l}\text { MNE- } \\
\text { PHIL }\end{array}$ & $\begin{array}{l}\text { MNE- } \\
\text { PHIL }\end{array}$ & $\begin{array}{l}\text { VARIABL. } \\
\text { (CONT'D) }\end{array}$ & $\begin{array}{l}\text { MNE- } \\
\text { PHIL }\end{array}$ & $\begin{array}{l}\text { MNE- } \\
\text { PHIL }\end{array}$ & $\begin{array}{l}\text { MNE- } \\
\text { PHIL }\end{array}$ & $\begin{array}{l}\text { MNE- } \\
\text { PHIL }\end{array}$ \\
\hline Male & $\begin{array}{c}0.0033 \\
(0.0079)\end{array}$ & $\begin{array}{c}0.0089 \\
(0.0073)\end{array}$ & $\begin{array}{c}0.0089 \\
(0.0073)\end{array}$ & $\begin{array}{c}0.0074 \\
(0.0073)\end{array}$ & OreExp & & $\begin{array}{c}-0.51 * * * \\
(0.18)\end{array}$ & $\begin{array}{c}-0.51^{* * * *} \\
(0.18)\end{array}$ & $\begin{array}{c}-0.51 * * * \\
(0.17)\end{array}$ \\
\hline Age & $\begin{array}{c}-0.0016^{* * *} \\
(0.00033)\end{array}$ & $\begin{array}{c}-0.0018^{* * *} \\
(0.00033)\end{array}$ & $\begin{array}{c}-0.0018^{* * *} \\
(0.00033)\end{array}$ & $\begin{array}{c}-0.0018^{* * *} \\
(0.00032)\end{array}$ & TradeOpen & & $\begin{array}{c}0.090 \\
(0.079)\end{array}$ & $\begin{array}{c}0.088 \\
(0.079)\end{array}$ & $\begin{array}{c}0.087 \\
(0.079)\end{array}$ \\
\hline Degree & $\begin{array}{l}0.027^{* * *} \\
(0.0042)\end{array}$ & $\begin{array}{c}0.026 * * * \\
(0.0049)\end{array}$ & $\begin{array}{c}0.026^{* * *} \\
(0.0049)\end{array}$ & $\begin{array}{c}-0.17^{* * *} \\
(0.042)\end{array}$ & CapDev & & $\begin{array}{l}0.061 * * \\
(0.027)\end{array}$ & $\begin{array}{l}0.061 * * \\
(0.027)\end{array}$ & $\begin{array}{l}0.060 * * \\
(0.027)\end{array}$ \\
\hline WrkSup & $\begin{array}{c}0.031^{* * *} \\
(0.0093)\end{array}$ & $\begin{array}{l}0.024^{* *} \\
(0.011)\end{array}$ & $\begin{array}{l}0.024^{* *} \\
(0.011)\end{array}$ & $\begin{array}{c}0.024^{* *} \\
(0.010)\end{array}$ & TFP & & $\begin{array}{l}-0.048 \\
(0.080)\end{array}$ & $\begin{array}{l}-0.051 \\
(0.079)\end{array}$ & $\begin{array}{l}-0.048 \\
(0.080)\end{array}$ \\
\hline FirmOwn & $\begin{array}{l}0.0040 \\
(0.029)\end{array}$ & $\begin{array}{c}0.019 \\
(0.030)\end{array}$ & $\begin{array}{c}-1.37^{* *} \\
(0.54)\end{array}$ & $\begin{array}{c}0.020 \\
(0.030)\end{array}$ & Corr & & $\begin{array}{c}0.056^{* * *} \\
(0.011)\end{array}$ & $\begin{array}{c}0.056^{* * *} \\
(0.011)\end{array}$ & $\begin{array}{c}0.057^{* * * *} \\
(0.011)\end{array}$ \\
\hline RelIncome & $\begin{array}{l}0.027^{* * *} \\
(0.0058)\end{array}$ & $\begin{array}{c}0.027^{* * *} \\
(0.0059)\end{array}$ & $\begin{array}{c}0.027^{* * * *} \\
(0.0059)\end{array}$ & $\begin{array}{l}0.028^{* * * *} \\
(0.0059)\end{array}$ & Democ & & $\begin{array}{c}-0.011 \\
(0.022)\end{array}$ & $\begin{array}{c}-0.011 \\
(0.022)\end{array}$ & $\begin{array}{l}-0.017 \\
(0.022)\end{array}$ \\
\hline Cosmopol & $\begin{array}{c}0.039 * * * \\
(0.0040)\end{array}$ & $\begin{array}{c}0.037^{* * *} \\
(0.0051)\end{array}$ & $\begin{array}{c}0.037^{* * *} \\
(0.0051)\end{array}$ & $\begin{array}{c}0.037^{* * *} \\
(0.0050)\end{array}$ & PolGlob & & $\begin{array}{l}-0.0028 \\
(0.0019)\end{array}$ & $\begin{array}{l}-0.0028 \\
(0.0019)\end{array}$ & $\begin{array}{c}-0.0030 \\
(0.0019)\end{array}$ \\
\hline TradePhob & $\begin{array}{c}-0.040 * * * \\
(0.0094)\end{array}$ & $\begin{array}{c}-0.045^{* * *} * \\
(0.0094)\end{array}$ & $\begin{array}{c}-0.045^{* * *} \\
(0.0094)\end{array}$ & $\begin{array}{c}-0.045^{* * *} \\
(0.0094)\end{array}$ & SocGlob & & $\begin{array}{c}-0.0074^{* * *} \\
(0.0013)\end{array}$ & $\begin{array}{c}-0.0074^{* * *} \\
(0.0013)\end{array}$ & $\begin{array}{c}-0.0072^{* *} \\
(0.0013)\end{array}$ \\
\hline $\begin{array}{r}\text { Country } \\
\text { fixed effects }\end{array}$ & yes & no & no & no & $\begin{array}{l}\text { FirmOwn \# } \\
\text { GDP p.c. }\end{array}$ & & & $\begin{array}{c}0.14^{* *} \\
(0.054)\end{array}$ & \\
\hline GDP p.c. & & $\begin{array}{l}-0.028 \\
(0.054)\end{array}$ & $\begin{array}{l}-0.028 \\
(0.054)\end{array}$ & $\begin{array}{l}-0.085 \\
(0.054)\end{array}$ & $\begin{array}{l}\text { Degree \# } \\
\text { GDP p.c. }\end{array}$ & & & & $\begin{array}{l}0.020^{* * *} \\
(0.0043)\end{array}$ \\
\hline GINI & & $\begin{array}{c}-0.83^{* *} \\
(0.33)\end{array}$ & $\begin{array}{c}-0.83^{* *} \\
(0.33)\end{array}$ & $\begin{array}{c}-0.86^{* *} \\
(0.32)\end{array}$ & Constant & $0.36 * * *$ & $1.35^{* *}$ & $1.35^{* *}$ & $1.98 * * *$ \\
\hline FDIStock & & $\begin{array}{l}0.099 \\
(0.10)\end{array}$ & $\begin{array}{c}0.10 \\
(0.10)\end{array}$ & $\begin{array}{c}0.10 \\
(0.10)\end{array}$ & & $(0.029)$ & $(0.53)$ & $(0.53)$ & $(0.53)$ \\
\hline FuelExp & & $\begin{array}{l}0.24 * * * \\
(0.085)\end{array}$ & $\begin{array}{l}0.24 * * * \\
(0.086)\end{array}$ & $\begin{array}{l}0.22^{* *} \\
(0.085)\end{array}$ & $\begin{array}{r}\text { Obs. } \\
\text { R2 }\end{array}$ & $\begin{array}{c}24,890 \\
0.090\end{array}$ & $\begin{array}{l}24,890 \\
0.075\end{array}$ & $\begin{array}{c}24,890 \\
0.076\end{array}$ & $\begin{array}{c}24,890 \\
0.076\end{array}$ \\
\hline
\end{tabular}

Robust standard errors clustere
$* * * \mathrm{p}<0.01, * * \mathrm{p}<0.05,{ }^{*} \mathrm{p}<0.1$

Table 6: Robustness test: Trade attitudes

Full regression table in table 16

The table shows that controlling for respondents' attitude towards free trade doesn't change the previous results on the determinants of the attitude towards FDI. This is a particularly strong finding since many determinants of individuals' attitudes towards MNEs may be highly correlated with their attitude towards free trade. The coefficients in table 6 thus capture the "pure/direct" effects of socioeconomic characteristics and macroeconomic factors, while the "total" effect would also include the influence that is operating via agents' attitude towards goods and services trade. 


\section{Population weights}

In the sample we use, the relative number of observations from different countries does not reflect differences in country sizes. The ISSP deliberately aims at surveying an approximately equal amount of persons from each country in the sample. This implies that, relative to the real country size, some environments are over-represented in terms of observations. In order to check whether our results also apply to a representative individual sampled from the countries covered by the ISSP, we adjust our estimations by applying weights that represent countries' relative size. ${ }^{15}$ The weights are designed as to make all observations from one country together reflect the relative country size in terms of the relevant population older than 15. For respondent $i$ in country $c$, it is computed as the ratio of the real population size to the number of observations from that country in the sample: ${ }^{16}$

$$
\text { Weight }_{i c}=\frac{\text { Population }(\geq 15 y r s)_{c}}{\text { Observations }_{c}}
$$

The data on working-age population are taken from the WDI. We then run the regressions (1) - (3) with the respective weights applied to each observation. The results are shown in table 7 , and table 17, respectively. They show that the relative over-representation of some countries does not drive our results, and that these findings also apply to a representative sample whose composition reflects relative country sizes.

\section{Factor endowments}

In section 5, we argued that differentiated effects of firm ownership and skill level between rich and poor countries can be explained by differences in relative factor endowments in these countries. We therefore used GDP per capita as a proxy for either type of relative factor abundance, capital and high skill. This was straightforward and allowed us to think about differences in the perceived distributional effects of financial integration between different countries comprehensively. However, we can test the hypotheses on differentiated effects of individual characteristics more directly by accounting for the interaction of either type of endowment at the country level with the respective relative individual endowment. To this end, we take data from the Penn World Tables on the aggregate capital stock (in 2005 PPP-US\$) and relate this to the size of a country's labor force to create a measure of relative capital abundance $(C a p A b)$. For high-skill abundance, we use the average years of schooling in a country (HumCapAb), retrieved from the Barro-Lee dataset (Barro and Lee, 2013). We

\footnotetext{
${ }^{15}$ Note that this does not fully solve the problem of external validity. Our analysis can only make a statement on the average answer of persons who live in the countries in which the survey was conducted.

${ }^{16}$ See e.g. Cameron and Trivedi (2010), p.113 ff.
} 


\begin{tabular}{|c|c|c|c|c|c|c|c|c|c|}
\hline & (1) & (2) & (3) & (4) & & (1) & (2) & (3) & (4) \\
\hline & OLS & OLS & OLS & OLS & & OLS & OLS & OLS & OLS \\
\hline VARIABL. & $\begin{array}{l}\text { MNE- } \\
\text { PHIL }\end{array}$ & $\begin{array}{l}\text { MNE- } \\
\text { PHIL }\end{array}$ & $\begin{array}{l}\text { MNE- } \\
\text { PHIL }\end{array}$ & $\begin{array}{l}\text { MNE- } \\
\text { PHIL }\end{array}$ & $\begin{array}{l}\text { VARIABL. } \\
\text { (CONT'D) }\end{array}$ & $\begin{array}{l}\text { MNE- } \\
\text { PHIL }\end{array}$ & $\begin{array}{l}\text { MNE- } \\
\text { PHIL }\end{array}$ & $\begin{array}{l}\text { MNE- } \\
\text { PHIL }\end{array}$ & $\begin{array}{l}\text { MNE- } \\
\text { PHIL }\end{array}$ \\
\hline Male & $\begin{array}{c}0.0058 \\
(0.0077)\end{array}$ & $\begin{array}{c}0.0078 \\
(0.0075)\end{array}$ & $\begin{array}{c}0.0078 \\
(0.0075)\end{array}$ & $\begin{array}{c}0.0065 \\
(0.0076)\end{array}$ & TradeOpen & & $\begin{array}{c}0.10 \\
(0.087)\end{array}$ & $\begin{array}{c}0.10 \\
(0.087)\end{array}$ & $\begin{array}{c}0.098 \\
(0.088)\end{array}$ \\
\hline Age & $\begin{array}{c}-0.0027^{* * * *} \\
(0.00056)\end{array}$ & $\begin{array}{c}-0.0029^{* * *} \\
(0.00051)\end{array}$ & $\begin{array}{c}-0.0029^{* * * *} \\
(0.00051)\end{array}$ & $\begin{array}{c}-0.0030^{* * *} \\
(0.00050)\end{array}$ & CapDev & & $\begin{array}{l}0.060^{*} \\
(0.033)\end{array}$ & $\begin{array}{l}0.060^{*} \\
(0.033)\end{array}$ & $\begin{array}{l}0.060^{*} \\
(0.033)\end{array}$ \\
\hline Degree & $\begin{array}{c}0.027^{* * *} \\
(0.0051)\end{array}$ & $\begin{array}{c}0.024 * * * \\
(0.0050)\end{array}$ & $\begin{array}{c}0.024^{* * *} \\
(0.0050)\end{array}$ & $\begin{array}{c}-0.13^{* *} \\
(0.055)\end{array}$ & TFP & & $\begin{array}{l}-0.096 \\
(0.12)\end{array}$ & $\begin{array}{r}-0.096 \\
(0.12)\end{array}$ & $\begin{array}{l}-0.098 \\
(0.12)\end{array}$ \\
\hline WrkSup & $\begin{array}{r}-0.0078 \\
(0.023)\end{array}$ & $\begin{array}{l}-0.012 \\
(0.022)\end{array}$ & $\begin{array}{l}-0.011 \\
(0.022)\end{array}$ & $\begin{array}{l}-0.011 \\
(0.022)\end{array}$ & Corr & & $\begin{array}{c}0.049^{* * *} \\
(0.013)\end{array}$ & $\begin{array}{c}0.049^{* * *} \\
(0.013)\end{array}$ & $\begin{array}{c}0.050^{* * *} \\
(0.014)\end{array}$ \\
\hline FirmOwn & $\begin{array}{c}0.022 \\
(0.064)\end{array}$ & $\begin{array}{c}0.034 \\
(0.062)\end{array}$ & $\begin{array}{c}-1.28^{* *} \\
(0.53)\end{array}$ & $\begin{array}{c}0.034 \\
(0.062)\end{array}$ & Democ & & $\begin{array}{c}0.025 \\
(0.023)\end{array}$ & $\begin{array}{c}0.026 \\
(0.023)\end{array}$ & $\begin{array}{c}0.020 \\
(0.024)\end{array}$ \\
\hline RelIncome & $\begin{array}{l}0.027^{* * *} \\
(0.0074)\end{array}$ & $\begin{array}{c}0.029 * * * \\
(0.0076)\end{array}$ & $\begin{array}{c}0.029 * * * \\
(0.0075)\end{array}$ & $\begin{array}{l}0.030 * * * \\
(0.0073)\end{array}$ & PolGlob & & $\begin{array}{l}-0.0040 \\
(0.0025)\end{array}$ & $\begin{array}{c}-0.0040 \\
(0.0025)\end{array}$ & $\begin{array}{l}-0.0043 \\
(0.0025)\end{array}$ \\
\hline Cosmopol & $\begin{array}{l}0.036^{* * *} \\
(0.0051)\end{array}$ & $\begin{array}{l}0.037^{* * *} \\
(0.0045)\end{array}$ & $\begin{array}{c}0.037^{* * *} \\
(0.0045)\end{array}$ & $\begin{array}{l}0.038^{* * *} \\
(0.0046)\end{array}$ & SocGlob & & $\begin{array}{c}-0.0060^{* * *} \\
(0.0012)\end{array}$ & $\begin{array}{c}-0.0061^{* * *} \\
(0.0013)\end{array}$ & $\begin{array}{c}-0.0058^{* * *} * \\
(0.0012)\end{array}$ \\
\hline $\begin{array}{r}\text { Country } \\
\text { fixed effects }\end{array}$ & yes & no & no & no & $\begin{array}{l}\text { FirmOwn \# } \\
\text { GDP p.c. }\end{array}$ & & & $\begin{array}{l}0.13^{* *} \\
(0.054)\end{array}$ & \\
\hline GDP p.c. & & $\begin{array}{l}-0.036 \\
(0.067)\end{array}$ & $\begin{array}{l}-0.036 \\
(0.067)\end{array}$ & $\begin{array}{l}-0.083 \\
(0.068)\end{array}$ & $\begin{array}{l}\text { Degree \# } \\
\text { GDP p.c. }\end{array}$ & & & & $\begin{array}{l}0.015^{* * *} \\
(0.0053)\end{array}$ \\
\hline GINI & & $\begin{array}{l}-0.65 \\
(0.40)\end{array}$ & $\begin{array}{l}-0.65 \\
(0.40)\end{array}$ & $\begin{array}{l}-0.71 * \\
(0.40)\end{array}$ & & & & & \\
\hline FDIStock & & $\begin{array}{r}-0.032 \\
(0.11)\end{array}$ & $\begin{array}{r}-0.028 \\
(0.11)\end{array}$ & $\begin{array}{l}-0.032 \\
(0.12)\end{array}$ & Constant & $\begin{array}{c}0.31 * * * \\
(0.029)\end{array}$ & $\begin{array}{c}1.12 \\
(0.75)\end{array}$ & $\begin{array}{c}1.11 \\
(0.75)\end{array}$ & $\begin{array}{c}1.67^{* *} \\
(0.77)\end{array}$ \\
\hline FuelExp & & $\begin{array}{l}0.32 * * \\
(0.12)\end{array}$ & $0.33^{* *}$ & $0.31^{* *}$ & Obs. & 25.673 & 25.673 & 25673 & 25.673 \\
\hline OreExp & & $\begin{array}{l}-0.46^{*} \\
(0.26)\end{array}$ & $\begin{array}{l}-0.46^{*} \\
(0.26)\end{array}$ & $\begin{array}{l}-0.45^{*} \\
(0.26)\end{array}$ & $\mathrm{R} 2$ & 0.061 & 0.052 & 0.053 & 0.053 \\
\hline
\end{tabular}

Table 7: Robustness test: Sample weights

Full regression table in table 17

then include both variables as country-level variables in our regressions and interact them with the individual endowments (FirmOwn and Degree, respectively), similar to the strategy in section 5. Note that we leave per-capita GDP as an explanatory country level variable in the regressions in order to disentangle the separate effect of factor abundance from the effect of per-capita income. Table 8 reports the results of interest, a complete regression table is again provided in the appendix in table 18 .

Column 1 shows the results when including capital abundance as an additional country level characteristic. The coefficient shows a negative sign, but is insignificant. The relative capital abundance in a country has no explanatory power on average attitudes towards FDI, and being a firm owner has no significant effect either. This changes when it is interacted with the level of capital abundance (column 2). The significantly negative coefficient shows that it is indeed the case that firm owners in capital scarce countries tend to dislike FDI whereas they have a more positive attitude in capital-abundant countries (the interaction term). Again, the change in sign of the combined effect of FirmOwn occurs within the middle quartiles of the sample in terms of capital abundance.

Columns 3 and 4 do the same for human-capital abundance. Here, the overall level in a country has a significantly positive effect when included on its own. This is in line with the empirical literature, that views the level of human capital in a country as decisive for 


\begin{tabular}{|c|c|c|c|c|}
\hline & (1) & $(2)$ & (3) & (4) \\
\hline & OLS & OLS & OLS & OLS \\
\hline VARIABLES & MNE-PHIL & MNE-PHIL & MNE-PHIL & MNE-PHIL \\
\hline Degree & $\begin{array}{c}0.027 * * * \\
(0.0048)\end{array}$ & $\begin{array}{c}0.027^{* * * *} \\
(0.0048)\end{array}$ & $\begin{array}{c}0.024 * * * \\
(0.0046)\end{array}$ & $\begin{array}{l}-0.027 \\
(0.030)\end{array}$ \\
\hline FirmOwn & $\begin{array}{c}0.021 \\
(0.031)\end{array}$ & $\begin{array}{l}-0.12^{*} \\
(0.070)\end{array}$ & $\begin{array}{c}0.025 \\
(0.031)\end{array}$ & $\begin{array}{c}0.025 \\
(0.030)\end{array}$ \\
\hline $\begin{array}{r}\text { Individual } \\
\text { controls }\end{array}$ & yes & yes & yes & yes \\
\hline GDP p.c. & $\begin{array}{c}0.027 \\
(0.070)\end{array}$ & $\begin{array}{c}0.028 \\
(0.070)\end{array}$ & $\begin{array}{l}-0.046 \\
(0.056)\end{array}$ & $\begin{array}{l}-0.055 \\
(0.057)\end{array}$ \\
\hline $\begin{array}{r}\text { Country level } \\
\text { controls }\end{array}$ & yes & yes & yes & yes \\
\hline $\mathrm{CapAb}$ & $\begin{array}{l}-5.7 \mathrm{e}-07 \\
(5.1 \mathrm{e}-07)\end{array}$ & $\begin{array}{c}-5.9 \mathrm{e}-07 \\
(5.1 \mathrm{e}-07)\end{array}$ & & \\
\hline HumCapAb & & & $\begin{array}{l}0.020 * * \\
(0.0074)\end{array}$ & $\begin{array}{c}0.0072 \\
(0.0094)\end{array}$ \\
\hline $\begin{array}{r}\text { FirmOwn \# } \\
\text { CapAb }\end{array}$ & & $\begin{array}{l}1.0 \mathrm{e}-06^{*} \\
(5.5 \mathrm{e}-07)\end{array}$ & & \\
\hline $\begin{array}{r}\text { Degree \# } \\
\text { HumCapAb }\end{array}$ & & & & $\begin{array}{c}0.0049 \\
(0.0029)\end{array}$ \\
\hline Constant & $\begin{array}{c}0.86 \\
(0.64)\end{array}$ & $\begin{array}{c}0.86 \\
(0.64)\end{array}$ & $\begin{array}{l}1.16^{* *} \\
(0.44)\end{array}$ & $\begin{array}{c}1.40^{* * *} \\
(0.46)\end{array}$ \\
\hline Observations & 25,673 & 25,673 & 25,673 & 25,673 \\
\hline $\mathrm{R} 2$ & 0.069 & 0.069 & 0.070 & 0.071 \\
\hline
\end{tabular}

Table 8: Robustness test: factor endowments Full regression table in table 18

the ability to experience gains from FDI (Borensztein et al. 1998) ${ }^{17}$ When comparing the effect of individual education in low-skill and high-skill abundant countries by including the interaction term with country skill abundance, the overall positive effect for Degree vanishes. Moreover, even though a differentiated effect of Degree in high- and low-skill abundant countries is still visible in the signs of the coefficients, it becomes marginally insignificant (with a p-value of 0.102 for the interaction term). This finding may be driven by the fact that "years of schooling" exhibit less cross-country variation than per-capita GDP. However, the combined effect of Degree is still positive and significant (at the 1\%-level) at the $75 \%$-quantile of countries in our sample in terms of HumCapAb (a country like Canada). Hence, there is a positive (combined) effect of the individual skill level in more skill-abundant countries, but that this effect vanishes in low-skill abundant countries.

\footnotetext{
${ }^{17}$ The fact that both HumCapAb and Degree have a significantly positive influence on people's attitudes towards MNEs shows that the "aggregate" effect of human capital at the country level goes beyond having many well-educated persons who, at the individual level, appreciate the presence of MNEs.
} 


\section{Summary and Conclusions}

In this paper we have analyzed the factors that determine individuals' attitudes towards multinational enterprises. Apart from highlighting the role of socio-economic characteristics at the individual level, we have identified some of the economic and institutional variables that cause the considerable cross-country differences in the assessment of MNEs. It turned out that, ceteris paribus, individuals living in countries that are characterized by a high degree of corruption and inequality are more likely to take a hostile attitude towards foreign companies. Moreover, financial development, the structure of exports and the degree of "social globalization" have a significant influence on a country's average perception of FDI.

In addition, we have demonstrated that the marginal effect of some individual characteristics on the attitude towards MNEs depends on country-specific variables, most importantly per-capita GDP: domestic firm owners view multinational firms more positively in rich countries than in poor countries. The same holds for individuals with a higher educational attainment. We interpret these results as evidence that the distributional consequences of FDI are perceived along the lines suggested by economic theory: in poor countries, the negative effect of FDI on the return to capital is more pronounced, generating a hostile attitude among incumbent entrepreneurs. Moreover, better educated persons in rich countries appreciate multinational enterprises' role in raising the demand for skilled labor - either by reinforcing Stolper-Samuelson effects or by predominantly engaging in horizontal FDI.

We believe that these results are important for (at least) two reasons: first, they contribute to a better understanding of individuals' support or discontent towards globalization in general, and multinational enterprises in particular. Moreover, they suggest that individuals, when defining their attitude towards multinational enterprises, are aware of the distributional implications of FDI, and that their judgement is guided by their own distributional interests. The next step would be to further disentangle the various - economic and non-economic - motivations that determine an individual's view on foreign firms, and to assess the relative importance of these motivations. While such an exercise is beyond the scope of this paper, it provides potential avenues for future research. 


\section{References}

Arteta, C., Eichengreen, B. and Wyplosz, C. (2001), When Does Capital Account Liberalization Help More Than it Hurts?, CEPR Discussion Papers 2910, C.E.P.R. Discussion Papers.

Bailliu, J. (2000), Private capital flows, financial development, and economic growth in developing countries, Working papers, Bank of Canada.

Barro, R. J. and Lee, J. W. (2013), 'A new data set of educational attainment in the world, 1950-2010', Journal of development economics 104, 184-198.

Borensztein, E., De Gregorio, J. and Lee, J.-W. (1998), 'How does foreign direct investment affect economic growth?', Journal of international Economics 45(1), 115-135.

Bryan, M. L. and Jenkins, S. P. (2013), Regression Analysis of Country Effects Using Multilevel Data: A Cautionary Tale, Discussion Papers 7583, IZA.

Bussiere, M. and Fratzscher, M. (2008), 'Financial openness and growth: Short-run gain, long-run pain?', Review of International Economics 16(1), 69-95.

Cadot, O., Geoffard, P.-Y., Suwa-Eisenmann, A. and Verdier, T. (2006), 'Scared by foreigners and their products? survey evidence from france'.

Cameron, A. C. and Trivedi, P. K. (2010), Microeconometrics using stata, Stata Press College Station, TX.

Carr, D. L., Markusen, J. R. and Maskus, K. E. (2001), 'Estimating the knowledge-capital model of the multinational enterprise', The American Economic Review 91(3), pp. 693708.

Davies, R. B. (2008), 'Hunting high and low for vertical FDI', Review of International Economics 16(2), 250-267.

Dreher, A. (2006), 'Does globalization affect growth? evidence from a new index of globalization', Applied Economics 38(10), 1091-1110.

Edwards, S. (2001), Capital mobility and economic performance: Are emerging economies different?, Working Paper 8076, National Bureau of Economic Research.

Feenstra, R. C. and Hanson, G. H. (1997), 'Foreign direct investment and relative wages: Evidence from mexico's maquiladoras', Journal of International Economics 42(3-4), 371393. 
Goldberg, P. K. and Pavcnik, N. (2007), 'Distributional effects of globalization in developing countries', Journal of Economic Literature 45(1), pp. 39-82.

Hanson, G. H., Mataloni Jr, R. J. and Slaughter, M. J. (2005), 'Vertical production networks in multinational firms', Review of Economics and statistics 87(4), 664-678.

Harrison, A. and Rodríguez-Clare, A. (2010), 'Trade, foreign investment, and industrial policy for developing countries', Handbook of Development Economics 5, 4039-4214.

Kaya, A. and Walker, J. T. (2012), 'The legitimacy of foreign investors: Individual attitudes toward the impact of multinational enterprises', Multinational Business Review 20, pp.266-295.

Kose, M. A., Prasad, E., Rogoff, K. and Wei, S.-J. (2009), 'Financial Globalization: A Reappraisal', IMF Staff Papers 56(1), 8-62.

Krugman, P. R. (2008), 'Trade and wages, reconsidered', Brookings Papers on Economic Activity 2008, pp. 103-137.

Mayda, A. M. and Rodrik, D. (2005), 'Why are some people (and countries) more protectionist than others?', European Economic Review 49(6), 1393 - 1430.

Morrow, P. M. (2010), 'Ricardian-heckscher-ohlin comparative advantage: Theory and evidence', Journal of International Economics 82(2), 137 - 151.

Noland, M. (2005), 'Popular attitudes, globalization and risk', International Finance 8(2), 199-229.

Ortseifer, C. and Schwab, J. (2015), 'Reaping the gains: Specialization and capital flows'. Unpublished manuscript, Gutenberg University of Mainz.

Romalis, J. (2004), 'Factor proportions and the structure of commodity trade', The American Economic Review 94(1), pp. 67-97.

Scheve, K. F. and Slaughter, M. J. (2001), Globalization and the perceptions of American workers, Peterson Institute.

Yeaple, S. R. (2003), 'The complex integration strategies of multinationals and cross country dependencies in the structure of foreign direct investment', Journal of International Economics 60(2), 293-314. 


\section{A Variables and summary statistics}

\begin{tabular}{l|l}
\hline Variable & Description \\
\hline \hline Male & Dummy if respondent is Male \\
\hline Age & Age of respondent \\
\hline Degree & $\begin{array}{l}\text { Highest Degree of Education, from "No formal qualification" to "University } \\
\text { degree completed" }\end{array}$ \\
\hline WrkSup & Dummy if respondent supervises others at work \\
\hline FirmOwn & Dummy if respondent employs more than 10 employees \\
\hline RelIncome & Income of respondent relative to average income in country \\
\hline Cosmopol & Response to agreement on patriotic statement \\
\hline TradeAtt & Response to agreement on statement on free trade \\
\hline
\end{tabular}

Table 9: Variable description individual variables

\begin{tabular}{rrrrrr}
\hline Variable & Obs & Mean & Std. Dev. & Min & Max \\
\hline MNE $_{\text {Damage }}$ & 41560 & 2.40472 & 1.07773 & 1 & 5 \\
MNE-PHIL & 40919 & 0.39820 & 0.48953 & 0 & 1 \\
MNE-PHIL Active $^{4}$ & 40919 & 0.18708 & 0.38998 & 0 & 1 \\
MNE-ATT $^{4}$ & 40919 & 1.58528 & 0.78543 & 1 & 3 \\
Male & 45191 & 0.45879 & 0.49830 & 0 & 1 \\
Age & 45198 & 45.91 & 17.19 & 15 & 94 \\
Degree & 45198 & 2.70357 & 1.45937 & 0 & 5 \\
WrkSup & 42770 & 0.22845 & 0.41984 & 0 & 1 \\
FirmOwn & 41768 & 0.00876 & 0.09320 & 0 & 1 \\
RelIncome & 32351 & 1.00084 & 0.99019 & 0.00183 & 30.42361 \\
Cosmopol & 43039 & 2.55863 & 1.10188 & 1 & 5 \\
TradePhob & 39674 & 2.35890 & 0.94211 & 1 & 5 \\
\hline
\end{tabular}

Table 10: Summary statistics of individual characteristics 


\begin{tabular}{|c|c|c|}
\hline Variable & Description & Source \\
\hline GDP p.c. & $\log$ of per capita GDP, average 1999-2003 & World Bank World Development Indicators \\
\hline GINI & GINI coefficient, average $1999-2003$ & World Bank World Development Indicators \\
\hline FDIStock & Stock of inward FDI per GDP, average 1999-2003 & UNCTAD FDI/TNC Database, WDI \\
\hline FuelExp & Share of fuel products in merchandise exports, average 1999-2003 & World Bank World Development Indicators \\
\hline OreExp & Share of ore products in merchandise exports, average 1999-2003 & World Bank World Development Indicators \\
\hline TradeOpen & Sum of exports and imports divided by GDP, average 1999-2003 & World Bank World Development Indicators \\
\hline CapDev & $\begin{array}{l}\text { Total value of publicly traded stocks as a share of GDP, average 1999- } \\
2003\end{array}$ & World Bank World Development Indicators \\
\hline TFP & Total Factor Productivity, relative to U.S., average 1999-2003 & Penn World Tables \\
\hline Democ & $\begin{array}{l}\text { Comprehensive (polity 2) Index of democratic institutions, average } \\
\text { 1999-2003 }\end{array}$ & Polity IV \\
\hline PolGlob & KOF Index of Political Globalization, average 1999-2003 & Dreher $(2006)$ \\
\hline SocGlob & KOF Index of Social Globalization, average 1999-2003 & Dreher $(2006)$ \\
\hline $\mathrm{CapAb}$ & $\begin{array}{l}\text { Capital stock divided by labor force, in Mio PPP-US\$, average 1999- } \\
2003\end{array}$ & Penn World Tables \\
\hline HumCapAb & Average years of schooling in age group $>15$, in year 2000 & Barro \& Lee (2013) \\
\hline
\end{tabular}

Table 11: Variable description country-specific variables

\begin{tabular}{rrrrrr}
\hline Variable & Obs & Mean & Std. Dev. & Min & Max \\
\hline GDP p.c. & 32 & 9.871843 & 0.6272125 & 7.891331 & 10.68659 \\
GINI & 32 & 0.3359875 & 0.0677547 & 0.247 & 0.5206 \\
FDIStock & 32 & 0.3245 & 0.2247785 & 0.015 & 1.245 \\
FuelExp & 32 & 0.0945312 & 0.1881254 & 0.001 & 0.827 \\
OreExp & 32 & 0.0469375 & 0.0761594 & 0.004 & 0.426 \\
TradeOpen & 32 & 0.7811809 & 0.3427446 & 0.20515 & 1.70188 \\
CapDev & 32 & 0.5621031 & 0.6232287 & 0 & 2.2825 \\
TFP & 32 & 6.559375 & 2.322382 & 2.4 & 9.7 \\
Corr & 32 & 9.39375 & 1.137609 & 5.4 & 10 \\
Democ & 32 & 86.00825 & 10.73421 & 45.438 & 97.178 \\
PolGlob & 32 & 71.90581 & 14.25516 & 39.244 & 90.25 \\
SocGlob & 32 & 0.8056062 & 0.2498954 & 0.3391 & 1.5354 \\
CapAb & 32 & 137682.5 & 54762.18 & $27,736.90$ & $222,720.50$ \\
HumCapAb & 32 & 10.23 & 1.405948 & 6.71 & 12.69 \\
\hline
\end{tabular}

Table 12: Summary statistics of country-specific variables 


\section{B Additional full regression tables}

\begin{tabular}{|c|c|c|c|}
\hline & (1) & (2) & (3) \\
\hline VARIABLES & $\begin{array}{c}\text { OLS } \\
\text { MNE-PHIL }\end{array}$ & $\begin{array}{c}\text { Logit } \\
\text { MNE-PHIL }\end{array}$ & $\begin{array}{c}\text { OLogit } \\
\text { MNE-ATT }\end{array}$ \\
\hline Male & $\begin{array}{l}0.016 * * \\
(0.0070)\end{array}$ & $\begin{array}{l}0.015 * * \\
(0.0069)\end{array}$ & $0.12^{* * *}$ \\
\hline \multirow[t]{2}{*}{ Age } & $-0.0019 * * *$ & $-0.0019 * * *$ & $-0.0080 * * *$ \\
\hline & $(0.00032)$ & $(0.00032)$ & $(0.0014)$ \\
\hline \multirow[t]{2}{*}{ Degree } & $0.026^{* * *}$ & $0.026^{* * *}$ & $0.13^{* * *}$ \\
\hline & $(0.0051)$ & $(0.0048)$ & $(0.021)$ \\
\hline \multirow[t]{2}{*}{ WrkSup } & $0.026^{* *}$ & $0.025 * *$ & $0.14 * * *$ \\
\hline & $(0.011)$ & $(0.011)$ & $(0.048)$ \\
\hline \multirow[t]{2}{*}{ FirmOwn } & 0.022 & 0.021 & 0.15 \\
\hline & $(0.031)$ & $(0.030)$ & $(0.13)$ \\
\hline \multirow[t]{2}{*}{ RelIncome } & $0.029 * * *$ & $0.030 * * *$ & $0.14 * * *$ \\
\hline & $(0.0062)$ & $(0.0065)$ & $(0.030)$ \\
\hline \multirow[t]{2}{*}{ Cosmopol } & $0.034^{* * *}$ & $0.033^{* * *}$ & $0.16^{* * *}$ \\
\hline & $(0.0052)$ & $(0.0051)$ & $(0.024)$ \\
\hline \multirow[t]{2}{*}{ GDP p.c. } & -0.0060 & -0.0047 & 0.070 \\
\hline & $(0.060)$ & $(0.060)$ & $(0.28)$ \\
\hline \multirow[t]{2}{*}{ GINI } & $-0.81 * *$ & $-0.77^{* *}$ & $-3.07^{*}$ \\
\hline & $(0.35)$ & $(0.36)$ & $(1.69)$ \\
\hline \multirow[t]{2}{*}{ FDIStock } & 0.12 & 0.11 & 0.81 \\
\hline & $(0.10)$ & $(0.11)$ & $(0.54)$ \\
\hline \multirow[t]{2}{*}{ FuelExp } & $0.22^{* *}$ & $0.22^{* *}$ & $1.09 * *$ \\
\hline & $(0.086)$ & $(0.086)$ & $(0.49)$ \\
\hline \multirow[t]{2}{*}{ OreExp } & $-0.50 * *$ & $-0.52 * * *$ & $-2.78 * * *$ \\
\hline & $(0.19)$ & $(0.19)$ & $(0.95)$ \\
\hline \multirow[t]{2}{*}{ TradeOpen } & 0.095 & 0.098 & 0.38 \\
\hline & $(0.086)$ & $(0.085)$ & $(0.40)$ \\
\hline \multirow[t]{2}{*}{ CapDev } & $0.058 * *$ & $0.056 * *$ & 0.20 \\
\hline & $(0.028)$ & $(0.028)$ & $(0.13)$ \\
\hline \multirow[t]{2}{*}{ TFP } & -0.075 & -0.078 & -0.46 \\
\hline & $(0.083)$ & $(0.083)$ & $(0.43)$ \\
\hline \multirow[t]{2}{*}{ Corr } & $0.053 * * *$ & $0.053^{* * *}$ & $0.23^{* * *}$ \\
\hline & $(0.012)$ & $(0.012)$ & $(0.054)$ \\
\hline \multirow[t]{2}{*}{ Democ } & -0.012 & -0.012 & -0.068 \\
\hline & $(0.023)$ & $(0.024)$ & $(0.11)$ \\
\hline \multirow[t]{2}{*}{ PolGlob } & -0.0028 & -0.0028 & -0.012 \\
\hline & $(0.0021)$ & $(0.0020)$ & $(0.0097)$ \\
\hline \multirow[t]{2}{*}{ SocGlob } & $-0.0079 * * *$ & $-0.0076^{* * *}$ & $-0.037 * * *$ \\
\hline & $(0.0014)$ & $(0.0014)$ & $(0.0071)$ \\
\hline \multirow[t]{2}{*}{ Constant } & $1.09 *$ & & \\
\hline & $(0.59)$ & & \\
\hline \multirow[t]{2}{*}{ Cut 1} & & & -1.82 \\
\hline & & & $(2.75)$ \\
\hline \multirow[t]{2}{*}{ Cut 2} & & & -0.66 \\
\hline & & & $(2.76)$ \\
\hline Observations & 25,673 & 25,673 & 25,673 \\
\hline $\mathrm{R} 2$ & 0.069 & & \\
\hline Pseudo R2 & & 0.0526 & 0.0424 \\
\hline$\%$ correctly predicted & & 64.26 & \\
\hline
\end{tabular}

Robust standard errors clustered at the country level in parentheses
$* * * \mathrm{p}<0.01,{ }^{* *} \mathrm{p}<0.05,{ }^{*} \mathrm{p}<0.1$

Table 13: Complete regression table 3: Country-specific variables 


\begin{tabular}{|c|c|c|c|}
\hline & (1) & (2) & (3) \\
\hline VARIABLES & $\begin{array}{c}\text { OLS } \\
\text { MNE-PHIL }\end{array}$ & $\begin{array}{c}\text { OLS } \\
\text { MNE-PHIL }\end{array}$ & $\begin{array}{c}\text { OLS } \\
\text { MNE-PHIL }\end{array}$ \\
\hline Male & $\begin{array}{l}0.016 * * \\
(0.0071)\end{array}$ & $\begin{array}{c}0.014^{*} \\
(0.0071)\end{array}$ & $\begin{array}{c}0.014^{*} \\
(0.0071)\end{array}$ \\
\hline Age & $\begin{array}{c}-0.0019^{* * *} \\
(0.00032)\end{array}$ & $\begin{array}{c}-0.0019 * * * \\
(0.00032)\end{array}$ & $\begin{array}{c}-0.0019 * * * \\
(0.00031)\end{array}$ \\
\hline Degree & $\begin{array}{c}0.026 * * * \\
(0.0051)\end{array}$ & $\begin{array}{c}-0.16^{* * *} \\
(0.045)\end{array}$ & $\begin{array}{c}-0.16^{* * *} \\
(0.045)\end{array}$ \\
\hline WrkSup & $\begin{array}{c}0.026^{* *} \\
(0.011)\end{array}$ & $\begin{array}{c}0.027 * * \\
(0.011)\end{array}$ & $\begin{array}{c}0.026^{* *} \\
(0.011)\end{array}$ \\
\hline FirmOwn & $\begin{array}{c}-1.48 * * * \\
(0.53)\end{array}$ & $\begin{array}{c}0.023 \\
(0.031)\end{array}$ & $\begin{array}{c}-1.36^{* *} \\
(0.52)\end{array}$ \\
\hline RelIncome & $\begin{array}{c}0.029 * * * \\
(0.0062)\end{array}$ & $\begin{array}{c}0.031^{* * *} \\
(0.0061)\end{array}$ & $\begin{array}{c}0.031^{* * *} \\
(0.0061)\end{array}$ \\
\hline Cosmopol & $\begin{array}{c}0.034^{* * *} \\
(0.0052)\end{array}$ & $\begin{array}{c}0.035 * * * \\
(0.0050)\end{array}$ & $\begin{array}{c}0.035 * * * \\
(0.0051)\end{array}$ \\
\hline GDP p.c. & $\begin{array}{c}-0.0063 \\
(0.060)\end{array}$ & $\begin{array}{l}-0.060 \\
(0.060)\end{array}$ & $\begin{array}{l}-0.060 \\
(0.060)\end{array}$ \\
\hline GINI & $\begin{array}{c}-0.82^{* *} \\
(0.35)\end{array}$ & $\begin{array}{c}-0.84^{* *} \\
(0.34)\end{array}$ & $\begin{array}{c}-0.84^{* *} \\
(0.34)\end{array}$ \\
\hline FDIStock & $\begin{array}{c}0.13 \\
(0.10)\end{array}$ & $\begin{array}{c}0.12 \\
(0.10)\end{array}$ & $\begin{array}{c}0.13 \\
(0.10)\end{array}$ \\
\hline FuelExp & $\begin{array}{l}0.23^{* *} \\
(0.087)\end{array}$ & $\begin{array}{l}0.21^{* *} \\
(0.087)\end{array}$ & $\begin{array}{l}0.21^{* *} \\
(0.087)\end{array}$ \\
\hline OreExp & $\begin{array}{c}-0.50 * * \\
(0.19)\end{array}$ & $\begin{array}{c}-0.50^{* * *} \\
(0.18)\end{array}$ & $\begin{array}{c}-0.50^{* * *} \\
(0.18)\end{array}$ \\
\hline TradeOpen & $\begin{array}{c}0.094 \\
(0.086)\end{array}$ & $\begin{array}{c}0.093 \\
(0.086)\end{array}$ & $\begin{array}{c}0.091 \\
(0.086)\end{array}$ \\
\hline CapDev & $\begin{array}{c}0.058 * * \\
(0.028)\end{array}$ & $\begin{array}{c}0.057 * * \\
(0.027)\end{array}$ & $\begin{array}{c}0.057^{* *} \\
(0.027)\end{array}$ \\
\hline TFP & $\begin{array}{l}-0.078 \\
(0.083)\end{array}$ & $\begin{array}{l}-0.075 \\
(0.083)\end{array}$ & $\begin{array}{l}-0.078 \\
(0.083)\end{array}$ \\
\hline Corr & $\begin{array}{c}0.053^{* * *} \\
(0.012)\end{array}$ & $\begin{array}{c}0.053^{* * *} \\
(0.012)\end{array}$ & $\begin{array}{c}0.053^{* * *} \\
(0.012)\end{array}$ \\
\hline Democ & $\begin{array}{l}-0.011 \\
(0.023)\end{array}$ & $\begin{array}{l}-0.017 \\
(0.024)\end{array}$ & $\begin{array}{l}-0.016 \\
(0.024)\end{array}$ \\
\hline PolGlob & $\begin{array}{c}-0.0028 \\
(0.0021)\end{array}$ & $\begin{array}{c}-0.0030 \\
(0.0021)\end{array}$ & $\begin{array}{c}-0.0030 \\
(0.0021)\end{array}$ \\
\hline SocGlob & $\begin{array}{c}-0.0079 * * * \\
(0.0014)\end{array}$ & $\begin{array}{c}-0.0077 * * * \\
(0.0014)\end{array}$ & $\begin{array}{c}-0.0077 * * * \\
(0.0014)\end{array}$ \\
\hline $\begin{array}{r}\text { FirmOwn \# } \\
\text { GDP p.c. } \\
\text { Degree \# } \\
\text { GDP p.c. }\end{array}$ & $\begin{array}{c}0.15 * * * \\
(0.053)\end{array}$ & $\begin{array}{c}0.019 * * * \\
(0.0046)\end{array}$ & $\begin{array}{c}0.14 * * \\
(0.053) \\
0.018 * * * \\
(0.0046)\end{array}$ \\
\hline Constant & $\begin{array}{l}1.09 * \\
(0.59)\end{array}$ & $\begin{array}{c}1.69 * * * \\
(0.59)\end{array}$ & $\begin{array}{c}1.68 * * * \\
(0.59)\end{array}$ \\
\hline $\begin{array}{r}\text { Observations } \\
\mathrm{R} 2\end{array}$ & $\begin{array}{c}25,673 \\
0.069\end{array}$ & $\begin{array}{c}25,673 \\
0.070\end{array}$ & $\begin{array}{c}25,673 \\
0.070\end{array}$ \\
\hline
\end{tabular}

Table 14: Complete regression table 4: Interacted variables 


\begin{tabular}{|c|c|c|c|c|c|c|}
\hline & (1) & $(2)$ & (3) & (4) & (5) & (6) \\
\hline & OLS & Logit & OLS & Logit & OLS & OLS \\
\hline VARIABLES & $\begin{array}{c}\text { MNE- } \\
\text { PHIL }_{\text {Active }}\end{array}$ & $\begin{array}{c}\text { MNE- } \\
\text { PHIL }_{\text {Active }}\end{array}$ & $\begin{array}{c}\text { MNE- } \\
\text { PHIL }_{\text {Active }}\end{array}$ & $\begin{array}{c}\text { MNE- } \\
\text { PHIL }_{\text {Active }}\end{array}$ & $\begin{array}{c}\text { MNE- } \\
\text { PHIL }_{\text {Active }}\end{array}$ & $\begin{array}{c}\text { MNE- } \\
\text { PHIL }_{\text {Active }}\end{array}$ \\
\hline Male & $\begin{array}{c}0.034^{* * *} \\
(0.0064)\end{array}$ & $\begin{array}{c}0.037 * * * \\
(0.0054)\end{array}$ & $\begin{array}{c}0.039 * * * \\
(0.0068)\end{array}$ & $\begin{array}{c}0.041 * * * \\
(0.0062)\end{array}$ & $\begin{array}{c}0.040 * * * \\
(0.0065)\end{array}$ & $\begin{array}{c}0.038 * * * \\
(0.0064)\end{array}$ \\
\hline Age & $\begin{array}{c}-0.00066^{* *} \\
(0.00024)\end{array}$ & $\begin{array}{c}-0.00078^{* * *} \\
(0.00024)\end{array}$ & $\begin{array}{c}-0.00076^{* * *} \\
(0.00026)\end{array}$ & $\begin{array}{c}-0.00085^{* * *} \\
(0.00027)\end{array}$ & $\begin{array}{c}-0.00077^{* * *} \\
(0.00025)\end{array}$ & $\begin{array}{c}-0.00078^{* * *} \\
(0.00025)\end{array}$ \\
\hline Degree & $\begin{array}{c}0.020 * * * \\
(0.0042)\end{array}$ & $\begin{array}{c}0.022^{* * *} \\
(0.0029)\end{array}$ & $\begin{array}{c}0.020 * * * \\
(0.0044)\end{array}$ & $\begin{array}{c}0.022^{* * *} \\
(0.0035)\end{array}$ & $\begin{array}{c}0.020 * * * \\
(0.0043)\end{array}$ & $\begin{array}{c}-0.19 * * * \\
(0.042)\end{array}$ \\
\hline WrkSup & $\begin{array}{l}0.034^{* * * *} \\
(0.0080)\end{array}$ & $\begin{array}{l}0.032 * * * \\
(0.0065)\end{array}$ & $\begin{array}{c}0.031^{* * * *} \\
(0.0097)\end{array}$ & $\begin{array}{l}0.029 * * * \\
(0.0085)\end{array}$ & $\begin{array}{c}0.031^{* * * *} \\
(0.0095)\end{array}$ & $\begin{array}{c}0.031 * * * \\
(0.0093)\end{array}$ \\
\hline FirmOwn & $\begin{array}{c}0.021 \\
(0.025)\end{array}$ & $\begin{array}{c}0.014 \\
(0.019)\end{array}$ & $\begin{array}{c}0.033 \\
(0.024)\end{array}$ & $\begin{array}{c}0.022 \\
(0.018)\end{array}$ & $\begin{array}{c}-0.73^{*} \\
(0.41)\end{array}$ & $\begin{array}{c}0.034 \\
(0.024)\end{array}$ \\
\hline RelIncome & $\begin{array}{l}0.024 * * * \\
(0.0053)\end{array}$ & $\begin{array}{c}0.018 * * * \\
(0.0043)\end{array}$ & $\begin{array}{l}0.024 * * * \\
(0.0050)\end{array}$ & $\begin{array}{c}0.018 * * * \\
(0.0043)\end{array}$ & $\begin{array}{c}0.024 * * * \\
(0.0050)\end{array}$ & $\begin{array}{c}0.025 * * * \\
(0.0049)\end{array}$ \\
\hline Cosmopol & $\begin{array}{c}0.025 * * * \\
(0.0028)\end{array}$ & $\begin{array}{c}0.024 * * * \\
(0.0026)\end{array}$ & $\begin{array}{c}0.025 * * * \\
(0.0039)\end{array}$ & $\begin{array}{c}0.024^{* * * *} \\
(0.0040)\end{array}$ & $\begin{array}{c}0.024^{* * *} \\
(0.0038)\end{array}$ & $\begin{array}{c}0.025 * * * \\
(0.0037)\end{array}$ \\
\hline $\begin{array}{r}\text { Country fixed } \\
\text { effects }\end{array}$ & yes & yes & no & no & no & no \\
\hline GDP p.c. & & & $\begin{array}{c}0.056 \\
(0.051)\end{array}$ & $\begin{array}{c}0.052 \\
(0.052)\end{array}$ & $\begin{array}{c}0.056 \\
(0.051)\end{array}$ & $\begin{array}{r}-0.0035 \\
(0.051)\end{array}$ \\
\hline GINI & & & $\begin{array}{l}-0.33 \\
(0.28)\end{array}$ & $\begin{array}{l}-0.27 \\
(0.30)\end{array}$ & $\begin{array}{l}-0.32 \\
(0.28)\end{array}$ & $\begin{array}{l}-0.35 \\
(0.27)\end{array}$ \\
\hline FDIStock & & & $\begin{array}{c}0.24 * * \\
(0.11)\end{array}$ & $\begin{array}{l}0.19^{*} \\
(0.10)\end{array}$ & $\begin{array}{c}0.24 * * \\
(0.11)\end{array}$ & $\begin{array}{c}0.24 * * \\
(0.11)\end{array}$ \\
\hline FuelExp & & & $\begin{array}{l}0.19^{*} \\
(0.10)\end{array}$ & $\begin{array}{l}0.17^{* *} \\
(0.081)\end{array}$ & $\begin{array}{c}0.19^{*} \\
(0.11)\end{array}$ & $\begin{array}{c}0.17 \\
(0.10)\end{array}$ \\
\hline OreExp & & & $\begin{array}{c}-0.52^{* * *} \\
(0.16)\end{array}$ & $\begin{array}{c}-0.53^{* * * *} \\
(0.17)\end{array}$ & $\begin{array}{c}-0.52^{* * *} \\
(0.16)\end{array}$ & $\begin{array}{c}-0.52^{* * * *} \\
(0.16)\end{array}$ \\
\hline TradeOpen & & & $\begin{array}{c}0.033 \\
(0.067)\end{array}$ & $\begin{array}{c}0.053 \\
(0.070)\end{array}$ & $\begin{array}{c}0.033 \\
(0.067)\end{array}$ & $\begin{array}{c}0.031 \\
(0.067)\end{array}$ \\
\hline CapDev & & & $\begin{array}{c}0.013 \\
(0.025)\end{array}$ & $\begin{array}{l}0.0068 \\
(0.026)\end{array}$ & $\begin{array}{c}0.014 \\
(0.026)\end{array}$ & $\begin{array}{c}0.013 \\
(0.025)\end{array}$ \\
\hline TFP & & & $\begin{array}{l}-0.12 \\
(0.095)\end{array}$ & $\begin{array}{c}-0.13 \\
(0.082)\end{array}$ & $\begin{array}{c}-0.11 \\
(0.095)\end{array}$ & $\begin{array}{c}-0.11 \\
(0.093)\end{array}$ \\
\hline Corr & & & $\begin{array}{c}0.029 * * * \\
(0.0092)\end{array}$ & $\begin{array}{l}0.034^{* * * *} \\
(0.0098)\end{array}$ & $\begin{array}{c}0.028^{* * * *} \\
(0.0093)\end{array}$ & $\begin{array}{l}0.028^{* * * *} \\
(0.0090)\end{array}$ \\
\hline Democ & & & $\begin{array}{l}-0.016 \\
(0.020)\end{array}$ & $\begin{array}{l}-0.020 \\
(0.019)\end{array}$ & $\begin{array}{l}-0.016 \\
(0.019)\end{array}$ & $\begin{array}{l}-0.022 \\
(0.019)\end{array}$ \\
\hline PolGlob & & & $\begin{array}{l}-0.0014 \\
(0.0017)\end{array}$ & $\begin{array}{l}-0.0014 \\
(0.0016)\end{array}$ & $\begin{array}{l}-0.0014 \\
(0.0017)\end{array}$ & $\begin{array}{l}-0.0016 \\
(0.0017)\end{array}$ \\
\hline SocGlob & & & $\begin{array}{c}-0.0068 * * * \\
(0.0013)\end{array}$ & $\begin{array}{c}-0.0064^{* * *} \\
(0.0012)\end{array}$ & $\begin{array}{c}-0.0068 * * * \\
(0.0013)\end{array}$ & $\begin{array}{c}-0.0066^{* * *} \\
(0.0013)\end{array}$ \\
\hline $\begin{array}{l}\text { FirmOwn \# } \\
\text { GDP p.c. } \\
\text { Degree \# } \\
\text { GDP p.c. }\end{array}$ & & & & & $\begin{array}{l}0.077 * \\
(0.041)\end{array}$ & $\begin{array}{l}0.021 * * * \\
(0.0044)\end{array}$ \\
\hline Constant & $\begin{array}{r}-0.0047 \\
(0.020)\end{array}$ & & $\begin{array}{c}0.15 \\
(0.48)\end{array}$ & & $\begin{array}{c}0.15 \\
(0.48)\end{array}$ & $\begin{array}{c}0.81 \\
(0.49)\end{array}$ \\
\hline Observations & 25,673 & 25,673 & 24,890 & 24,890 & 25,673 & 25,673 \\
\hline R-squared & 0.085 & & 0.064 & & 0.064 & 0.065 \\
\hline $\begin{array}{r}\text { Pseudo R2 } \\
\% \text { corr. pred }\end{array}$ & & $\begin{array}{c}0.09 \\
82.01\end{array}$ & & $\begin{array}{l}0.066 \\
81.71\end{array}$ & & \\
\hline
\end{tabular}

Robust standard errors clustered at the country level in parentheses

*** $\mathrm{p}<0.01,{ }^{* *} \mathrm{p}<0.05,{ }^{*} \mathrm{p}<0.1$

Table 15: Complete regression table 5: MNE-PHIL ${ }_{\text {Active }}$ 


\begin{tabular}{|c|c|c|c|c|c|c|c|c|}
\hline & (1) & (2) & (3) & (4) & (5) & (6) & (7) & (8) \\
\hline & OLS & Logit & Ologit & OLS & Logit & Ologit & OLS & OLS \\
\hline VARIABLES & MNE-PHIL & MNE-PHIL & MNE-ATT & MNE-PHIL & MNE-PHIL & MNE-ATT & MNE-PHIL & MNE-PHIL \\
\hline Male & $\begin{array}{c}0.0033 \\
(0.0079)\end{array}$ & $\begin{array}{c}0.0030 \\
(0.0076)\end{array}$ & $\begin{array}{l}0.068^{* *} \\
(0.035)\end{array}$ & $\begin{array}{c}0.0089 \\
(0.0073)\end{array}$ & $\begin{array}{c}0.0083 \\
(0.0072)\end{array}$ & $\begin{array}{c}0.091 * * * \\
(0.034)\end{array}$ & $\begin{array}{c}0.0089 \\
(0.0073)\end{array}$ & $\begin{array}{c}0.0074 \\
(0.0073)\end{array}$ \\
\hline Age & $\begin{array}{c}-0.0016^{* * *} \\
(0.00033)\end{array}$ & $\begin{array}{c}-0.0017^{* * *} \\
(0.00032)\end{array}$ & $\begin{array}{c}-0.0072^{* * *} \\
(0.0014)\end{array}$ & $\begin{array}{c}-0.0018^{* * *} \\
(0.00033)\end{array}$ & $\begin{array}{c}-0.0019^{* * *} \\
(0.00032)\end{array}$ & $\begin{array}{c}-0.0078^{* * *} \\
(0.0014)\end{array}$ & $\begin{array}{c}-0.0018^{* * *} \\
(0.00033)\end{array}$ & $\begin{array}{c}-0.0018^{* * *} \\
(0.00032)\end{array}$ \\
\hline Degree & $\begin{array}{c}0.027 * * * \\
(0.0042)\end{array}$ & $\begin{array}{c}0.027^{* * *} \\
(0.0037)\end{array}$ & $\begin{array}{c}0.13^{* * *} \\
(0.018)\end{array}$ & $\begin{array}{c}0.026^{* * *} \\
(0.0049)\end{array}$ & $\begin{array}{c}0.026 * * * \\
(0.0046)\end{array}$ & $\begin{array}{l}0.13^{* * *} \\
(0.021)\end{array}$ & $\begin{array}{c}0.026^{* * *} \\
(0.0049)\end{array}$ & $\begin{array}{c}-0.17^{* * *} \\
(0.042)\end{array}$ \\
\hline WrkSup & $\begin{array}{l}0.031^{* * *} \\
(0.0093)\end{array}$ & $\begin{array}{l}0.030^{* * *} \\
(0.0091)\end{array}$ & $\begin{array}{c}0.16^{* * *} \\
(0.040)\end{array}$ & $\begin{array}{l}0.024^{* *} \\
(0.011)\end{array}$ & $\begin{array}{l}0.023^{* *} \\
(0.010)\end{array}$ & $\begin{array}{l}0.13^{* * *} \\
(0.046)\end{array}$ & $\begin{array}{l}0.024^{* *} \\
(0.011)\end{array}$ & $\begin{array}{l}0.024 * * \\
(0.010)\end{array}$ \\
\hline FirmOwn & $\begin{array}{l}0.0040 \\
(0.029)\end{array}$ & $\begin{array}{c}0.0023 \\
(0.028)\end{array}$ & $\begin{array}{c}0.044 \\
(0.13)\end{array}$ & $\begin{array}{c}0.019 \\
(0.030)\end{array}$ & $\begin{array}{c}0.017 \\
(0.029)\end{array}$ & $\begin{array}{c}0.12 \\
(0.13)\end{array}$ & $\begin{array}{c}-1.37^{* *} \\
(0.54)\end{array}$ & $\begin{array}{c}0.020 \\
(0.030)\end{array}$ \\
\hline RelIncome & $\begin{array}{c}0.027^{* * *} \\
(0.0058)\end{array}$ & $\begin{array}{c}0.027^{* * *} \\
(0.0062)\end{array}$ & $\begin{array}{c}0.13^{* * *} \\
(0.029)\end{array}$ & $\begin{array}{l}0.027^{* * *} \\
(0.0059)\end{array}$ & $\begin{array}{c}0.027 * * * \\
(0.0062)\end{array}$ & $\begin{array}{l}0.13^{* * *} \\
(0.029)\end{array}$ & $\begin{array}{c}0.027^{* * *} \\
(0.0059)\end{array}$ & $\begin{array}{l}0.028^{* * *} \\
(0.0059)\end{array}$ \\
\hline Cosmopol & $\begin{array}{l}0.039^{* * *} \\
(0.0040)\end{array}$ & $\begin{array}{c}0.039 * * * \\
(0.0036)\end{array}$ & $\begin{array}{c}0.19^{* * *} \\
(0.017)\end{array}$ & $\begin{array}{l}0.037^{* * *} \\
(0.0051)\end{array}$ & $\begin{array}{l}0.036 * * * \\
(0.0050)\end{array}$ & $\begin{array}{c}0.17^{* * *} \\
(0.024)\end{array}$ & $\begin{array}{l}0.037^{* * *} \\
(0.0051)\end{array}$ & $\begin{array}{l}0.037^{* * *} \\
(0.0050)\end{array}$ \\
\hline TradePhob & $\begin{array}{c}-0.040^{* * *} \\
(0.0094)\end{array}$ & $\begin{array}{c}-0.040^{* * *} \\
(0.0095)\end{array}$ & $\begin{array}{c}-0.23^{* * *} \\
(0.047)\end{array}$ & $\begin{array}{c}-0.045^{* * *} \\
(0.0094)\end{array}$ & $\begin{array}{c}-0.045^{* * *} \\
(0.0094)\end{array}$ & $\begin{array}{c}-0.24 * * * \\
(0.047)\end{array}$ & $\begin{array}{c}-0.045^{* * *} \\
(0.0094)\end{array}$ & $\begin{array}{c}-0.045 * * * \\
(0.0094)\end{array}$ \\
\hline $\begin{array}{r}\text { Country } \\
\text { fixed effects }\end{array}$ & yes & yes & yes & no & no & no & no & no \\
\hline GDP p.c. & & & & $\begin{array}{l}-0.028 \\
(0.054)\end{array}$ & $\begin{array}{c}-0.028 \\
(0.053)\end{array}$ & $\begin{array}{c}-0.044 \\
(0.25)\end{array}$ & $\begin{array}{c}-0.028 \\
(0.054)\end{array}$ & $\begin{array}{l}-0.085 \\
(0.054)\end{array}$ \\
\hline GINI & & & & $\begin{array}{c}-0.83^{* *} \\
(0.33)\end{array}$ & $\begin{array}{c}-0.79^{* *} \\
(0.34)\end{array}$ & $\begin{array}{c}-3.19^{* *} \\
(1.61)\end{array}$ & $\begin{array}{c}-0.83^{* *} \\
(0.33)\end{array}$ & $\begin{array}{c}-0.86^{* *} \\
(0.32)\end{array}$ \\
\hline FDIStock & & & & $\begin{array}{c}0.099 \\
(0.10)\end{array}$ & $\begin{array}{c}0.089 \\
(0.10)\end{array}$ & $\begin{array}{c}0.69 \\
(0.55)\end{array}$ & $\begin{array}{c}0.10 \\
(0.10)\end{array}$ & $\begin{array}{c}0.10 \\
(0.10)\end{array}$ \\
\hline FuelExp & & & & $\begin{array}{c}0.24^{* * *} \\
(0.085)\end{array}$ & $\begin{array}{c}0.23^{* * *} \\
(0.086)\end{array}$ & $\begin{array}{c}1.15^{* *} \\
(0.50)\end{array}$ & $\begin{array}{l}0.24 * * * \\
(0.086)\end{array}$ & $\begin{array}{l}0.22^{* *} \\
(0.085)\end{array}$ \\
\hline OreExp & & & & $\begin{array}{c}-0.51^{* * * *} \\
(0.18)\end{array}$ & $\begin{array}{c}-0.53^{* * *} \\
(0.18)\end{array}$ & $\begin{array}{c}-2.79^{* * * *} \\
(0.90)\end{array}$ & $\begin{array}{c}-0.51^{* * * *} \\
(0.18)\end{array}$ & $\begin{array}{c}-0.51^{* * *} \\
(0.17)\end{array}$ \\
\hline TradeOpen & & & & $\begin{array}{c}0.090 \\
(0.079)\end{array}$ & $\begin{array}{c}0.092 \\
(0.079)\end{array}$ & $\begin{array}{c}0.35 \\
(0.37)\end{array}$ & $\begin{array}{c}0.088 \\
(0.079)\end{array}$ & $\begin{array}{c}0.087 \\
(0.079)\end{array}$ \\
\hline CapDev & & & & $\begin{array}{l}0.061^{* *} \\
(0.027)\end{array}$ & $\begin{array}{c}0.059^{* *} \\
(0.028)\end{array}$ & $\begin{array}{l}0.23^{*} \\
(0.13)\end{array}$ & $\begin{array}{l}0.061^{* *} \\
(0.027)\end{array}$ & $\begin{array}{l}0.060^{* *} \\
(0.027)\end{array}$ \\
\hline TFP & & & & $\begin{array}{l}-0.048 \\
(0.080)\end{array}$ & $\begin{array}{l}-0.050 \\
(0.080)\end{array}$ & $\begin{array}{c}-0.30 \\
(0.43)\end{array}$ & $\begin{array}{l}-0.051 \\
(0.079)\end{array}$ & $\begin{array}{l}-0.048 \\
(0.080)\end{array}$ \\
\hline Corr & & & & $\begin{array}{c}0.056^{* * *} \\
(0.011)\end{array}$ & $\begin{array}{c}0.056^{* * * *} \\
(0.011)\end{array}$ & $\begin{array}{l}0.24^{* * *} \\
(0.051)\end{array}$ & $\begin{array}{c}0.056 * * * \\
(0.011)\end{array}$ & $\begin{array}{c}0.057^{* * *} \\
(0.011)\end{array}$ \\
\hline Democ & & & & $\begin{array}{l}-0.011 \\
(0.022)\end{array}$ & $\begin{array}{l}-0.012 \\
(0.022)\end{array}$ & $\begin{array}{l}-0.065 \\
(0.11)\end{array}$ & $\begin{array}{l}-0.011 \\
(0.022)\end{array}$ & $\begin{array}{l}-0.017 \\
(0.022)\end{array}$ \\
\hline PolGlob & & & & $\begin{array}{l}-0.0028 \\
(0.0019)\end{array}$ & $\begin{array}{l}-0.0028 \\
(0.0018)\end{array}$ & $\begin{array}{c}-0.012 \\
(0.0089)\end{array}$ & $\begin{array}{l}-0.0028 \\
(0.0019)\end{array}$ & $\begin{array}{l}-0.0030 \\
(0.0019)\end{array}$ \\
\hline SocGlob & & & & $\begin{array}{c}-0.0074^{* * *} \\
(0.0013)\end{array}$ & $\begin{array}{c}-0.0071^{* * *} \\
(0.0013)\end{array}$ & $\begin{array}{c}-0.034 * * * \\
(0.0065)\end{array}$ & $\begin{array}{c}-0.0074^{* * *} \\
(0.0013)\end{array}$ & $\begin{array}{c}-0.0072^{* * *} \\
(0.0013)\end{array}$ \\
\hline $\begin{array}{l}\text { FirmOwn \# } \\
\text { GDP p.c. } \\
\text { Degree \# } \\
\text { GDP p.c. }\end{array}$ & & & & & & & $\begin{array}{c}0.14^{* *} \\
(0.054)\end{array}$ & $\begin{array}{c}0.020 * * * \\
(0.0043)\end{array}$ \\
\hline Constant & $\begin{array}{c}0.36^{* * *} \\
(0.029)\end{array}$ & & & $\begin{array}{l}1.35^{* *} \\
(0.53)\end{array}$ & & & $\begin{array}{l}1.35^{* *} \\
(0.53)\end{array}$ & $\begin{array}{c}1.98^{* * *} \\
(0.53)\end{array}$ \\
\hline Cut1 & & & $\begin{array}{c}0.66^{* * *} \\
(0.13)\end{array}$ & & & $\begin{array}{l}-3.19 \\
(2.54)\end{array}$ & & \\
\hline Cut 2 & & & $\begin{array}{c}1.85^{* * * *} \\
(0.11)\end{array}$ & & & $\begin{array}{l}-2.02 \\
(2.54)\end{array}$ & & \\
\hline Observations & 24,890 & 24,890 & 24,890 & 24,890 & 24,890 & 24,890 & 24,890 & 24,890 \\
\hline $\begin{array}{r}\mathrm{R} 2 \\
\text { Pseudo R2 } \\
\text { \% corr. pred. }\end{array}$ & 0.090 & $\begin{array}{c}0.07 \\
64.83\end{array}$ & 0.059 & 0.075 & $\begin{array}{c}0.058 \\
64.2\end{array}$ & 0.048 & 0.076 & 0.076 \\
\hline
\end{tabular}

Robust standard errors clustered at the country level in parentheses

Table 16: Complete regression results table 6: Control for Trade Attitudes 


\begin{tabular}{|c|c|c|c|c|c|c|c|c|}
\hline & (1) & (2) & (3) & (4) & $(5)$ & (6) & $(7)$ & (8) \\
\hline & OLS & Logit & Ologit & OLS & Logit & Ologit & OLS & OLS \\
\hline VARIABLES & MNE-PHIL & MNE-PHIL & MNE-ATT & MNE-PHIL & MNE-PHIL & MNE-ATT & MNE-PHIL & MNE-PHIL \\
\hline Male & $\begin{array}{c}0.0058 \\
(0.0077)\end{array}$ & $\begin{array}{c}0.0053 \\
(0.0075)\end{array}$ & $\begin{array}{c}0.070^{*} \\
(0.041)\end{array}$ & $\begin{array}{c}0.0078 \\
(0.0075)\end{array}$ & $\begin{array}{c}0.0072 \\
(0.0073)\end{array}$ & $\begin{array}{c}0.079 * * \\
(0.040)\end{array}$ & $\begin{array}{c}0.0078 \\
(0.0075)\end{array}$ & $\begin{array}{c}0.0065 \\
(0.0076)\end{array}$ \\
\hline Age & $\begin{array}{c}-0.0027^{* * *} \\
(0.00056)\end{array}$ & $\begin{array}{c}-0.0028^{* * *} \\
(0.00051)\end{array}$ & $\begin{array}{c}-0.011^{* * *} \\
(0.0022)\end{array}$ & $\begin{array}{c}-0.0029^{* * *} \\
(0.00051)\end{array}$ & $\begin{array}{c}-0.0030^{* * *} \\
(0.00048)\end{array}$ & $\begin{array}{c}-0.012^{* * *} \\
(0.0020)\end{array}$ & $\begin{array}{c}-0.0029^{* * *} \\
(0.00051)\end{array}$ & $\begin{array}{c}-0.0030^{* * *} \\
(0.00050)\end{array}$ \\
\hline Degree & $\begin{array}{c}0.027^{* * *} \\
(0.0051)\end{array}$ & $\begin{array}{c}0.028^{* * *} \\
(0.0050)\end{array}$ & $\begin{array}{l}0.13^{* * *} \\
(0.024)\end{array}$ & $\begin{array}{l}0.024^{* * *} \\
(0.0050)\end{array}$ & $\begin{array}{c}0.024^{* * *} \\
(0.0049)\end{array}$ & $\begin{array}{l}0.11^{* * *} \\
(0.023)\end{array}$ & $\begin{array}{c}0.024^{* * *} \\
(0.0050)\end{array}$ & $\begin{array}{l}-0.13^{* *} \\
(0.055)\end{array}$ \\
\hline WrkSup & $\begin{array}{c}-0.0078 \\
(0.023)\end{array}$ & $\begin{array}{l}-0.0069 \\
(0.023)\end{array}$ & $\begin{array}{l}0.0016 \\
(0.10)\end{array}$ & $\begin{array}{l}-0.012 \\
(0.022)\end{array}$ & $\begin{array}{l}-0.011 \\
(0.022)\end{array}$ & $\begin{array}{l}-0.016 \\
(0.097)\end{array}$ & $\begin{array}{c}-0.011 \\
(0.022)\end{array}$ & $\begin{array}{c}-0.011 \\
(0.022)\end{array}$ \\
\hline FirmOwn & $\begin{array}{c}0.022 \\
(0.064)\end{array}$ & $\begin{array}{c}0.021 \\
(0.062)\end{array}$ & $\begin{array}{c}0.091 \\
(0.26)\end{array}$ & $\begin{array}{c}0.034 \\
(0.062)\end{array}$ & $\begin{array}{c}0.033 \\
(0.060)\end{array}$ & $\begin{array}{c}0.15 \\
(0.25)\end{array}$ & $\begin{array}{c}-1.28^{* *} \\
(0.53)\end{array}$ & $\begin{array}{c}0.034 \\
(0.062)\end{array}$ \\
\hline RelIncome & $\begin{array}{l}0.027^{* * *} \\
(0.0074)\end{array}$ & $\begin{array}{c}0.027^{* * *} \\
(0.0075)\end{array}$ & $\begin{array}{c}0.14^{* * *} \\
(0.037)\end{array}$ & $\begin{array}{c}0.029^{* * *} \\
(0.0076)\end{array}$ & $\begin{array}{c}0.029^{* * *} \\
(0.0077)\end{array}$ & $\begin{array}{c}0.14^{* * *} \\
(0.038)\end{array}$ & $\begin{array}{c}0.029^{* * *} \\
(0.0075)\end{array}$ & $\begin{array}{c}0.030^{* * *} \\
(0.0073)\end{array}$ \\
\hline Cosmopol & $\begin{array}{c}0.036^{* * *} \\
(0.0051)\end{array}$ & $\begin{array}{c}0.036^{* * *} \\
(0.0052)\end{array}$ & $\begin{array}{c}0.17^{* * *} \\
(0.027)\end{array}$ & $\begin{array}{l}0.037^{* * *} \\
(0.0045)\end{array}$ & $\begin{array}{c}0.037^{* * *} \\
(0.0046)\end{array}$ & $\begin{array}{c}0.17^{* * *} \\
(0.025)\end{array}$ & $\begin{array}{l}0.037^{* * *} \\
(0.0045)\end{array}$ & $\begin{array}{l}0.038^{* * *} \\
(0.0046)\end{array}$ \\
\hline $\begin{array}{r}\text { Country } \\
\text { fixed effects }\end{array}$ & yes & yes & yes & no & no & no & no & no \\
\hline GDP p.c. & & & & $\begin{array}{l}-0.036 \\
(0.067)\end{array}$ & $\begin{array}{c}-0.035 \\
(0.068)\end{array}$ & $\begin{array}{l}-0.055 \\
(0.31)\end{array}$ & $\begin{array}{l}-0.036 \\
(0.067)\end{array}$ & $\begin{array}{c}-0.083 \\
(0.068)\end{array}$ \\
\hline GINI & & & & $\begin{array}{l}-0.65 \\
(0.40)\end{array}$ & $\begin{array}{l}-0.62 \\
(0.41)\end{array}$ & $\begin{array}{l}-2.23 \\
(1.86)\end{array}$ & $\begin{array}{l}-0.65 \\
(0.40)\end{array}$ & $\begin{array}{l}-0.71^{*} \\
(0.40)\end{array}$ \\
\hline FDIStock & & & & $\begin{array}{c}-0.032 \\
(0.11)\end{array}$ & $\begin{array}{l}-0.047 \\
(0.12)\end{array}$ & $\begin{array}{c}0.20 \\
(0.56)\end{array}$ & $\begin{array}{l}-0.028 \\
(0.11)\end{array}$ & $\begin{array}{l}-0.032 \\
(0.12)\end{array}$ \\
\hline FuelExp & & & & $\begin{array}{c}0.32^{* *} \\
(0.12)\end{array}$ & $\begin{array}{l}0.33^{* *} \\
(0.13)\end{array}$ & $\begin{array}{c}1.70^{* * *} \\
(0.64)\end{array}$ & $\begin{array}{c}0.33^{* *} \\
(0.12)\end{array}$ & $\begin{array}{c}0.31^{* *} \\
(0.13)\end{array}$ \\
\hline OreExp & & & & $\begin{array}{l}-0.46^{*} \\
(0.26)\end{array}$ & $\begin{array}{l}-0.49^{*} \\
(0.28)\end{array}$ & $\begin{array}{c}-2.86^{* *} \\
(1.32)\end{array}$ & $\begin{array}{l}-0.46^{*} \\
(0.26)\end{array}$ & $\begin{array}{l}-0.45^{*} \\
(0.26)\end{array}$ \\
\hline TradeOpen & & & & $\begin{array}{c}0.10 \\
(0.087)\end{array}$ & $\begin{array}{c}0.11 \\
(0.089)\end{array}$ & $\begin{array}{c}0.35 \\
(0.40)\end{array}$ & $\begin{array}{c}0.10 \\
(0.087)\end{array}$ & $\begin{array}{c}0.098 \\
(0.088)\end{array}$ \\
\hline CapDev & & & & $\begin{array}{l}0.060^{*} \\
(0.033)\end{array}$ & $\begin{array}{l}0.060^{*} \\
(0.034)\end{array}$ & $\begin{array}{c}0.21 \\
(0.16)\end{array}$ & $\begin{array}{l}0.060^{*} \\
(0.033)\end{array}$ & $\begin{array}{l}0.060^{*} \\
(0.033)\end{array}$ \\
\hline TFP & & & & $\begin{array}{c}-0.096 \\
(0.12)\end{array}$ & $\begin{array}{c}-0.10 \\
(0.12)\end{array}$ & $\begin{array}{c}-0.69 \\
(0.57)\end{array}$ & $\begin{array}{c}-0.096 \\
(0.12)\end{array}$ & $\begin{array}{c}-0.098 \\
(0.12)\end{array}$ \\
\hline Corr & & & & $\begin{array}{c}0.049^{* * *} \\
(0.013)\end{array}$ & $\begin{array}{c}0.050^{* * *} \\
(0.014)\end{array}$ & $\begin{array}{c}0.21 * * * \\
(0.059)\end{array}$ & $\begin{array}{c}0.049^{* * *} \\
(0.013)\end{array}$ & $\begin{array}{c}0.050^{* * *} \\
(0.014)\end{array}$ \\
\hline Democ & & & & $\begin{array}{c}0.025 \\
(0.023)\end{array}$ & $\begin{array}{c}0.026 \\
(0.024)\end{array}$ & $\begin{array}{c}0.14 \\
(0.11)\end{array}$ & $\begin{array}{c}0.026 \\
(0.023)\end{array}$ & $\begin{array}{c}0.020 \\
(0.024)\end{array}$ \\
\hline PolGlob & & & & $\begin{array}{l}-0.0040 \\
(0.0025)\end{array}$ & $\begin{array}{l}-0.0041^{*} \\
(0.0025)\end{array}$ & $\begin{array}{c}-0.018^{*} \\
(0.011)\end{array}$ & $\begin{array}{l}-0.0040 \\
(0.0025)\end{array}$ & $\begin{array}{c}-0.0043 \\
(0.0025)\end{array}$ \\
\hline SocGlob & & & & $\begin{array}{c}-0.0060^{* * *} \\
(0.0012)\end{array}$ & $\begin{array}{c}-0.0059^{* * *} \\
(0.0013)\end{array}$ & $\begin{array}{c}-0.029^{* * *} \\
(0.0059)\end{array}$ & $\begin{array}{c}-0.0061^{* * *} \\
(0.0013)\end{array}$ & $\begin{array}{c}-0.0058^{* * *} \\
(0.0012)\end{array}$ \\
\hline $\begin{array}{c}\text { FirmOwn \# } \\
\text { GDP p.c. } \\
\text { Degree \# } \\
\text { GDP p.c. }\end{array}$ & & & & & & & $\begin{array}{l}0.13 * * \\
(0.054)\end{array}$ & $\begin{array}{c}0.015^{* * *} \\
(0.0053)\end{array}$ \\
\hline Constant & $\begin{array}{c}0.31 * * * \\
(0.029)\end{array}$ & & & $\begin{array}{c}1.12 \\
(0.75)\end{array}$ & & & $\begin{array}{l}1.11 \\
(0.75)\end{array}$ & $\begin{array}{l}1.67^{* *} \\
(0.77)\end{array}$ \\
\hline $\begin{array}{l}\text { Cut1 } \\
\text { Cut } 2\end{array}$ & & & $\begin{array}{c}1.00^{* * *} \\
(0.13) \\
2.22^{* * *} \\
(0.16)\end{array}$ & & & $\begin{array}{l}-1.62 \\
(3.46) \\
-0.41 \\
(3.46)\end{array}$ & & \\
\hline Observations & 25,673 & 25,673 & 25,673 & 25,673 & 25,673 & 25,673 & 25,673 & 25,673 \\
\hline $\begin{array}{r}\mathrm{R} 2 \\
\text { Pseudo } \mathrm{R} 2\end{array}$ & 0.061 & 0.047 & 0.039 & 0.052 & & 0.033 & 0.053 & 0.053 \\
\hline
\end{tabular}

Robust standard errors clustered
$* * * \mathrm{p}<0.01,{ }^{* *} \mathrm{p}<0.05,{ }^{*} \mathrm{p}<0.1$

Table 17: Complete regression results table 7: Sample weights 


\begin{tabular}{|c|c|c|c|c|}
\hline & (1) & $(2)$ & (3) & (4) \\
\hline \multirow[b]{2}{*}{ VARIABLES } & OLS & OLS & OLS & OLS \\
\hline & MNE-PHIL & MNE-PHIL & MNE-PHIL & MNE-PHIL \\
\hline \multirow[t]{2}{*}{ Male } & $0.016^{* *}$ & $0.016 * *$ & $0.016^{* *}$ & $0.015^{* *}$ \\
\hline & $(0.0070)$ & $(0.0070)$ & $(0.0070)$ & $(0.0071)$ \\
\hline \multirow[t]{2}{*}{ Age } & $-0.0019 * * *$ & $-0.0019 * * *$ & $-0.0019 * * *$ & $-0.0019 * * *$ \\
\hline & $(0.00032)$ & $(0.00032)$ & $(0.00032)$ & $(0.00031)$ \\
\hline \multirow[t]{2}{*}{ Degree } & $0.027 * * *$ & $0.027 * * *$ & $0.024^{* * *}$ & -0.027 \\
\hline & $(0.0048)$ & $(0.0048)$ & $(0.0046)$ & $(0.030)$ \\
\hline \multirow[t]{2}{*}{ WrkSup } & $0.026 * *$ & $0.026 * *$ & $0.025 * *$ & $0.026 * *$ \\
\hline & $(0.011)$ & $(0.011)$ & $(0.011)$ & $(0.011)$ \\
\hline \multirow[t]{2}{*}{ FirmOwn } & 0.021 & $-0.12^{*}$ & 0.025 & 0.025 \\
\hline & $(0.031)$ & $(0.070)$ & $(0.031)$ & $(0.030)$ \\
\hline \multirow[t]{2}{*}{ RelIncome } & $0.029 * * *$ & $0.029 * * *$ & $0.030 * * *$ & $0.031 * * *$ \\
\hline & $(0.0060)$ & $(0.0060)$ & $(0.0062)$ & $(0.0062)$ \\
\hline \multirow[t]{2}{*}{ Cosmopol } & $0.033 * * *$ & $0.033 * * *$ & $0.036^{* * *}$ & $0.037 * * *$ \\
\hline & $(0.0048)$ & $(0.0048)$ & $(0.0046)$ & $(0.0046)$ \\
\hline \multirow[t]{2}{*}{ GDP p.c. } & 0.027 & 0.028 & -0.046 & -0.055 \\
\hline & $(0.070)$ & $(0.070)$ & $(0.056)$ & $(0.057)$ \\
\hline \multirow[t]{2}{*}{ CapAb } & $-5.7 \mathrm{e}-07$ & $-5.9 \mathrm{e}-07$ & & \\
\hline & $(5.1 \mathrm{e}-07)$ & $(5.1 \mathrm{e}-07)$ & & \\
\hline \multirow[t]{2}{*}{ HumCapAb } & & & $0.020 * *$ & 0.0072 \\
\hline & & & $(0.0074)$ & $(0.0094)$ \\
\hline \multirow[t]{2}{*}{ GINI } & $-0.87 * *$ & $-0.87 * *$ & $-0.69 * *$ & $-0.74 * *$ \\
\hline & $(0.37)$ & $(0.37)$ & $(0.30)$ & $(0.30)$ \\
\hline \multirow[t]{2}{*}{ FDIStock } & 0.11 & 0.11 & 0.12 & 0.13 \\
\hline & $(0.10)$ & $(0.10)$ & $(0.098)$ & $(0.099)$ \\
\hline \multirow[t]{2}{*}{ FuelExp } & $0.23 * * *$ & $0.24 * * *$ & $0.24^{* *}$ & $0.24^{* *}$ \\
\hline & $(0.081)$ & $(0.081)$ & $(0.095)$ & $(0.093)$ \\
\hline \multirow[t]{2}{*}{ OreExp } & $-0.49 * * *$ & $-0.50 * * *$ & $-0.59 * * *$ & $-0.59 * * *$ \\
\hline & $(0.17)$ & $(0.17)$ & $(0.18)$ & $(0.18)$ \\
\hline \multirow{2}{*}{ TradeOpen } & 0.074 & 0.073 & 0.083 & 0.079 \\
\hline & $(0.086)$ & $(0.086)$ & $(0.081)$ & $(0.081)$ \\
\hline \multirow[t]{2}{*}{ CapDev } & $0.065^{* *}$ & $0.066^{* *}$ & $0.054^{* *}$ & $0.054 * *$ \\
\hline & $(0.029)$ & $(0.029)$ & $(0.023)$ & $(0.022)$ \\
\hline \multirow[t]{2}{*}{ TFP } & -0.083 & -0.085 & -0.049 & -0.046 \\
\hline & $(0.081)$ & $(0.081)$ & $(0.078)$ & $(0.078)$ \\
\hline \multirow[t]{2}{*}{ Corr } & $0.053 * * *$ & $0.053 * * *$ & $0.058 * * *$ & $0.059 * * *$ \\
\hline & $(0.011)$ & $(0.011)$ & $(0.011)$ & $(0.011)$ \\
\hline \multirow[t]{2}{*}{ Democ } & -0.0099 & -0.0097 & -0.012 & -0.012 \\
\hline & $(0.022)$ & $(0.022)$ & $(0.023)$ & $(0.023)$ \\
\hline PolGlob & -0.0030 & -0.0030 & -0.0022 & -0.0023 \\
\hline & $(0.0023)$ & $(0.0023)$ & $(0.0016)$ & $(0.0016)$ \\
\hline SocGlob & $-0.0076^{* * *}$ & $-0.0076^{* * *}$ & $-0.0081 * * *$ & $-0.0081 * * *$ \\
\hline & $(0.0015)$ & $(0.0015)$ & $(0.0014)$ & $(0.0014)$ \\
\hline FirmOwn \# & & $1.0 \mathrm{e}-06^{*}$ & & \\
\hline $\mathrm{CapAb}$ & & $(5.5 \mathrm{e}-07)$ & & \\
\hline Degree \# & & & & 0.0049 \\
\hline HumCapAb & & & & $(0.0029)$ \\
\hline Constant & 0.86 & 0.86 & $1.16^{* *}$ & $1.40 * * *$ \\
\hline & $(0.64)$ & $(0.64)$ & $(0.44)$ & $(0.46)$ \\
\hline Observations & 25,673 & 25,673 & 25,673 & 25,673 \\
\hline $\mathrm{R} 2$ & 0.069 & 0.069 & 0.070 & 0.071 \\
\hline
\end{tabular}

Robust standard errors clustered at the country level in parentheses *** $\mathrm{p}<0.01, * * \mathrm{p}<0.05$, * $\mathrm{p}<0.1$

Table 18: Complete regression results table 8 . Factor endowments 